OPEN ACCESS

Edited by:

Péter Szabó,

Institute of Botany (ASCR), Czechia

Reviewed by:

Richard Hoffmann

York University, Canada

Paul Humphries,

Charles Sturt University, Australia

*Correspondence:

lan D. Rotherham

i.d.rotherham@shu.ac.uk

Specialty section:

This article was submitted to

Biogeography and Macroecology,

a section of the journal

Frontiers in Ecology and Evolution

Received: 16 October 2020

Accepted: 01 February 2021

Published: 12 March 2021

Citation:

Rotherham ID (2021) The Impacts of Recolonisation of an Urbanised

River by Native and Non-native

Species. Front. Ecol. Evol. 9:618371.

doi: 10.3389/fevo.2021.618371

\section{The Impacts of Recolonisation of an Urbanised River by Native and Non-native Species}

\author{
Ian D. Rotherham*
}

Department of the Natural and Built Environment, Sheffield Hallam University, Sheffield, United Kingdom

The roles of native and non-native species in the recolonisation of the River Don in South Yorkshire, England, are considered through the lens of environmental history. Notable as one of the most polluted river systems in Western Europe, the Don-Dearne-Rother catchment runs west to east from South Yorkshire and North Derbyshire and drains a significance part of middle England. However, from their origins in the foothills of the high Pennine hills with peat-bogs and heather moorland, the constituent rivers run through upland-fringe farmland and then into the major urban and industrial centres of the region. By the mid-twentieth century the reaches of these watercourses were grossly polluted and physically degraded too. However, from the 1970s onward there began a slow recovery in environmental quality and this has continued to the present day. This paper focuses on the ecological changes in the main urban zones of the River Don catchment and includes the constituent rivers namely the Sheaf, the Porter, the Rother, the Dearne, the Rivelin, and the Loxley. Importantly, though conservationists may be reluctant to accept it, the new ecology which has emerged throughout the catchment is irreparably changed from that of the seventeenth and eighteenth centuries. That landscape itself was already majorly altered from the countryside described in the Domesday account of 1086, and that too was much changed from the Romano-British landscape of a millennium earlier. The landscape is changing and is permanently changed and so too is the ecology that it now supports. In this context, a hybrid or recombinant ecology has been observed to develop through the process of eco-fusion and is made up of an intimate mix of native and non-native species.

Keywords: native, non-native, recombinant ecology, eco-fusion, recolonisation, River Don

\section{INTRODUCTION-A LANDSCAPE TRANSFORMED}

This paper considers the ecological fluxes along the River Don catchment in South Yorkshire, United Kingdom. The study region is perhaps uniquely well recorded and described by the works of local historians and natural historians since the 1700s but with historical insights from earlier centuries too. By the mid-twentieth century the urban and industrial stretches of the watercourses of the River Don Catchment were radically changed from their condition only a century or two previously (Firth, 1997). In the 1600s and 1700s, these were mostly rural rivers with small urban settlements along the rivers at crossing points such as major bridges or else set a little way back from the valley-bottom floodplains (Rotherham and Cartwright, 2000; Rotherham, 2013a). 
Particularly in the lower-lying areas to the east, the flat, expansive floodplains were highly valued as productive meadows and often left undeveloped. Further eastwards the landscape was dominated by extensive fenlands and peat-bogs of the low-lying flatlands (Rotherham, 2010, 2018b). In the uplands to the west, the countryside was dominated by expansive peatlands of moor, bog, and woodlands (Rotherham, 2008b). Urban development was restricted to a few settlements of just a few thousand people, and industry was limited to localised developments centred on small, water-powered mills, and factories (Rotherham, 2018a). The middle ground between the high Pennine hills and the lowland fens was an intimate mix of commonland, hunting chase, managed enclosed woods, and farmland. Insights into the landscape and ecology of this time are derived from the records of the nationally significant botanist Jonathan Salt during the 1700s (Salt, 1889; Salt, unpublished) and from the writings of antiquarians and topographers (see Hey, 1998; Jones, 2009).

However, with coming of the Industrial Revolution of the 1700 s and 1800s, this situation changed dramatically (Hey, 1998; Jones, 2009; Rotherham, 2013a, 2018a). Rivers were straightened canalised and culverted, and their floodplains drained and developed. The upland bogs and moors were drained and large areas converted to farmland. The lowland fens and bogs were mostly drained and turned to intensive arable farming (Rotherham, 2008a, 2010, 2013b). Throughout the entire catchment the physical and ecological systems were transformed, and in the urban, industrial centres especially, these changes were absolute. With the decline beginning in earnest in the 1600s, there are no data on things like water chemistry, hydrology (flow or seasonality etc.) to act as any sort of baseline for comparison. However, we do know that at that time, the river catchment had its origins in intact and expansive peat bogs at around 1,200 feet (c. 400 meters) altitude to the north and west of Sheffield. The river water would be acidic in the upper catchment, relatively oligotrophic, and lacking obvious chemical pollutants such as heavy metals or petrochemical organic acids. Alongside processes of urbanisation the rivers were increasingly straightened, culverted and canalised; and importantly the upland bogs were drained and lands around turned from bog and moorland to "improved" under-drained farmland. An assumed impact of these changes has been to make the rivers more "flashy" and prone to both flooding and drought (Crowe and Rotherham, 2019). With urbanisation and industrialisation, the river system acted as an uncontrolled, open sewer for much of the expanding town and particularly for the increasing numbers of factories connected to the expanding steel industry and associated works (Walton, 1948). The industry lining the banks of the main arterial rivers, the Don, Sheaf, and Rother, poured uncontrolled and unregulated effluent into the watercourses and furthermore, they used the river-water as coolant for the industrial processes (Firth, 1997; Rotherham, 2017c). One consequence was that the urban River Don ran at a constant temperature of around twenty-one to twenty-three degrees Celsius winter and summer (Gilbert, 1989, 1992a; Firth, 1997). This both exacerbated organic pollution problems by increasing biological oxygen demand and also had direct impacts on associated plants and wildlife. By the early 1970s, the now canalised urban rivers were functionally separated from their floodplains and mixed raw domestic sewage from combined drainage systems with non-biodegradable detergents that led to sewage-contaminated foam blowing around rivers and into the wider landscape (Firth, 1997; Rotherham, 2013a, 2017c, 2018a,c).

In the wider environment there were further factors to complicate the situation. Gross air pollution from factories and now tens of thousands of coal-burning domestic fires meant severe acid rain along with other chemical pollutants from industry. Across the landscape this led to acidification of soils and changes in vegetation and fauna detectable from observations at the time and since. Acidification led to nutrient leaching from soils across the region and further contamination of watercourses. Added to this was the increasing burden of run-off by contaminated water from urban infrastructure such as roadways and railways, with oils and metals especially prevalent. In farmland particularly, the use of increasing quantities of persistent pesticides such as DDT (dichlorodiphenyltrichloroethane) removed most predatory birds including those of watercourses.

The research questions underlying this paper are:

(1) What were the historic drivers of environmental change in the River Don catchment?

(2) What patterns of change are discernible in the vegetation along the main rivers?

(3) What changes occurred amongst the macro-fauna?

(4) What recovery has taken place during the late twentieth century and early twenty-first century?

(5) How does the emerging ecology compare with that which was displaced?

(6) Are there any lessons for long-term restoration and recovery of damaged riverine systems?

\section{MATERIALS AND METHODS}

The study involves historical review of records and published sources for the region (including old photographs of the rivers and detailed botanical surveys) together with a longterm (50 year) observational study and action research with key stakeholders. Research studies undertaken during the 1970s, 1980s, and 1990s, fed into positive planning to restore the catchment and to establish major nature reserves and recreational access routes along the rivers. Following this work were workshops, seminars and a networking exercise with local stakeholders on non-native species. This paper presents summaries of key observations and trends over the study period rather than detailed datasets.

The author was involved in the surveys of the 1980s and 1990s, was responsible for policy development and documents for the greening of the River Don valley, and undertook action research and observational research over the period of the study. He also directed the establishment of protected areas and nature reserves throughout the catchment, established nature reserves, and cowrote the River Rother Wildlife Strategy (Rotherham et al., 1994). 
The depth of ecological research and the long timeline involved makes the River Don catchment almost unique as a case-study of these changes.

Finally, the ecological changes are analysed and considered in terms of the emergence of a "recombinant ecology" and of rewilding. The conceptual terms and assumptions with regard to "recombinance," to what is "natural" or "original," and in terms of "restoration" are discussed and defined elsewhere (e.g., Rotherham, 2014b, 2017a,b; Bridgewater and Rotherham, 2019).

\section{The City Region}

As a border town between north and south, from Roman times onward, the study region was significant in national politics and power (Walton, 1948; Hey, 1998). The great Saxon Kingdom of Northumbria extended from here north to Edinburgh, and to the south was Mercia, the powerhouse of a united English kingdom. The River Don divided the north from the south, a division reinforced by great wetlands and wooded areas of higher ground (Rotherham, 2017b). To this day, Sheffield is a border town; the south of the north rather than the north of the south, and the lowland edge of the uplands, not vice versa. Sheffield is the fourth largest city in England, and despite its history of steel, iron, coal and manufacturing, boasts more ancient woodlands than any other industrial centre in Western Europe (Rotherham, 2013a). The city is the central conurbation for South Yorkshire and North Derbyshire. It is a remarkable place with unique heritage and deep-seated contradictions in its character, its people and its heritage. Described by George Orwell in the Road to Wigan Pier, as the dirtiest, smelliest, ugliest city in the world, by the 1970s, its name became a by-word for clean air.

\section{'...But even Wigan is beautiful compared with Sheffield. Sheffield, I suppose, could justly claim to be called the ugliest town in the Old World; its inhabitants. Who want it to be pre-eminent in everything, very likely do make that claim for it..... And the stench! If at rare moments you stop smelling sulphur it is because you have begun smelling gas. Even the shallow river that runs through the town is usually bright yellow with some chemical or other. Once, I halted in the street and counted the factory chimneys I could see; there were thirty-three of them, but there would have been far more if the air had not been obscured by smoke.' Orwell, 1937.}

Orwell goes on to point out that whilst there is no inherent reason why industry should be dirty and ugly, "Northerners" had become used to and tolerant of these conditions. Today, as Jones (2009) noted, Sheffield is the most wooded industrial city in Western Europe. At the heart of this great city are its five rivers, the Rivelin, the Loxley, the Porter, the Sheaf, and of course the Don, and for the wider city region, the Dearne and the Rother. The Don is the largest of these watercourses. The rivers, the city, the people, are all intertwined, and Sheffield's poet, the Corn Law Rhymer, Ebenezer Elliot, wrote eloquently of the beauties of the Lower Don Valley:

"Don, like a weltering worm, lies blue below, And Wincobank, before me, rising green, Calls from the South the silvery Rother slow, And smile on moors beyond, and meads between,

\section{Unrivall'd landscape" Elliot, 1840.}

It is hard to imagine such a landscape when viewed from Wincobank Hill today. Yet this flatland between Sheffield centre where the main river crossing was at Lady's Bridge, and where the M1 motorway now runs, was once a great wetland. As quoted by the great antiquarian, Hunter (1819), in 1546, the ancient chapel at Attercliffe was still in use and the curate of Rotherham, at that time the major town and main ecclesiastical centre, would come to his flock when it was too wet for them to come to him "...... to mynistre to the seke people, as when the waters of the Rothere and Downe [DON] are so urgent that the curate of Rotherham cannot to them repayre, nor the inhabitants unto hym nether on horseback or bote. ....." Research showed how until the 1950s along the River Don and the nearby Rother, many local people kept boats in case the rivers burst their banks as they did several times a year (Rotherham, 2010). The catastrophic regional floods of 2007 and 2019 were reminders of the frailty of human superiority over nature.

\section{A Short Environmental History of the River Don Catchment}

The catchment of the River Don rises at $c .600 \mathrm{~m}$ on the millstone grit moorlands of the Peak District, northwest of Sheffield (see Figures 1, 2). Including its major tributaries, the Sheaf, Rother and Dearne, it drains a catchment of 1,849 square kilometres in which 1.4 million people live, work, recreate, use water and produce effluent (Edwards, 1997, 1998, 1999; Rotherham, 2017b, 2018a; Crowe and Rotherham, 2019). The catchment includes the major conurbations of Doncaster, Barnsley, Rotherham, Sheffield and Chesterfield. The River Rother rises south of Chesterfield before flowing northwards through urban and industrial areas around Chesterfield and Rotherham, to its confluence with the Don just east of Sheffield. The Dearne has its source on moors south and east of Huddersfield and west of Barnsley passing through Barnsley, Wath, and Mexborough to join the Don at Conisborough. The Don river-system descends quickly from the Pennine moors through deep valleys to Sheffield and Rotherham on Coal Measure Sandstones, through magnesian limestone ridge, into Doncaster and the bunter sandstones, and then across the low-lying floodplain to join the River Ouse at Goole, and then the River Trent (Firth, 1997; Edwards, 1998).

John Ruskin (1819-1900) art critic, poet, and political commentator, once described Sheffield as the "dolorous city on the dirty Don" (Belshaw, 2000). This is an apt description of the river's condition for nearly two centuries. Water quality is a particularly major issue for this industrialised and urbanised catchment. Its river systems were described in the 1970s, as amongst the most polluted in Europe. However, there were significant improvements in recent decades such as an initiative by Yorkshire Water Services called "Rivercare" (Anon, 2002). This $£ 400$ million investment across the region upgraded sewage treatment works and combined sewage overflows (Yorkshire Water Services Ltd., online, undated).

Crossley (1989) noted that there are few districts in Britain where rivers have been used for power as intensively as in the Don catchment. On almost 30 miles of five streams and their 


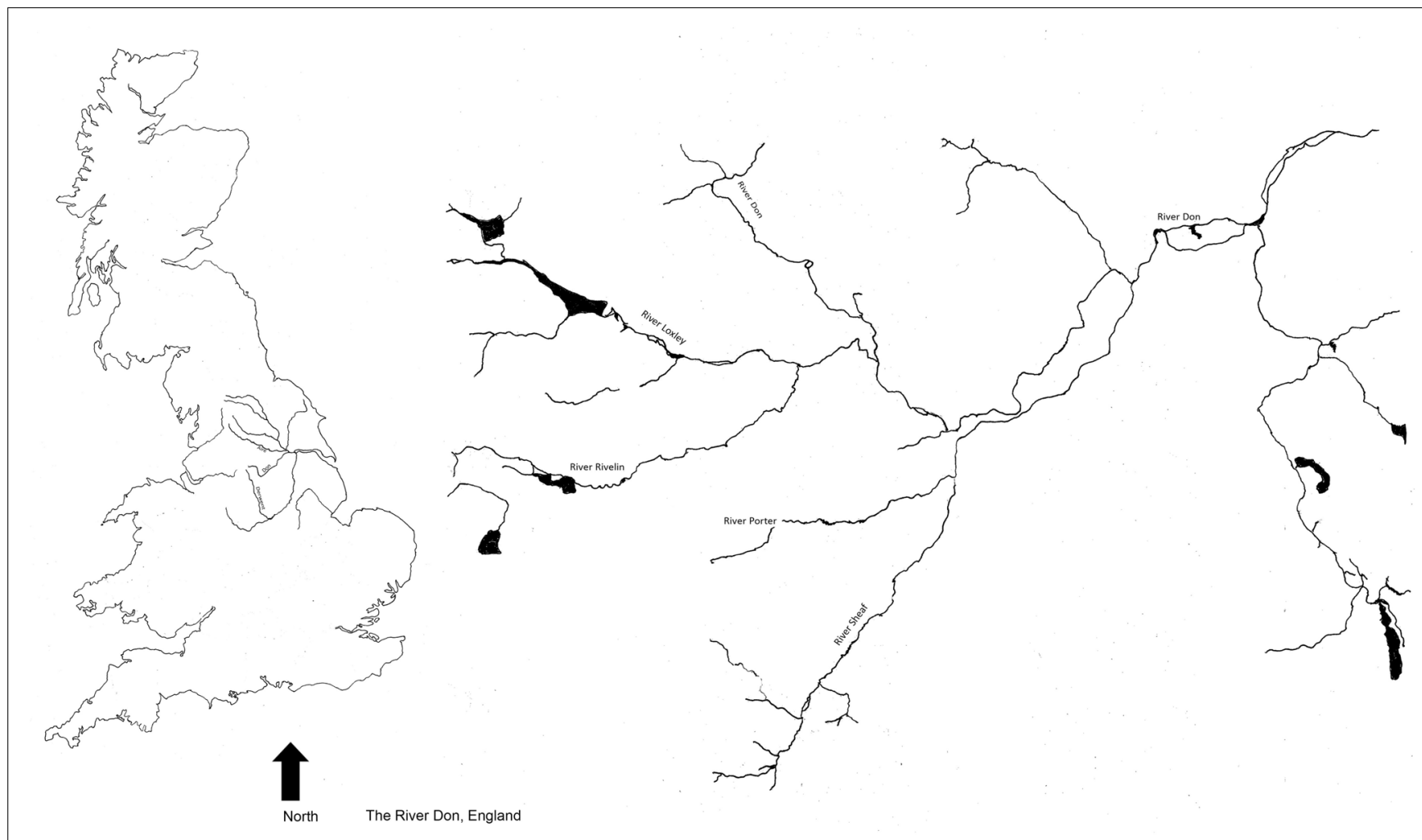

FIGURE 1 | River Don catchment location.

tributaries in the Sheffield area, are over 115 known locations of water-powered mills. The first recorded water-powered sites were in $1210 \mathrm{AD}$ when a collection of mills was constructed at Lady's Bridge in Sheffield centre. These mills were originally used for corn-milling, paper-making, or snuff-grinding, but most were later applied to the region's growing metal trades where water-wheels drove grindstones, forge-hammers, rolling-mills, and wire-mills. Alongside the direct industrial use for power, for water-supply, and for the discharge of effluent, came increasing despoliation through a growing human population without basic sanitation or services. Firth (1997) noted the report of the Medical Officer of the City of Sheffield in 1891 describing the sanitary situation:

\footnotetext{
"It would be hard to find in any town poorer conditions than are to be found in the centre of Sheffield. Nuisance and unsanitary conditions of every description abound. Diseases such as cholera and typhoid spread from privy middens and filthy unpaved courts into rubble sewers and contaminated water and waste flows down steep hills into the river and streams."
}

By the 1970s, the state of the chemical pollution of the rivers was dire and is well-illustrated by studies on the contamination of the River Rother (see Rotherham, 2008c). Amishah and Cowx (2000) confirmed that poor water quality was still limiting the potential recovery of much of the catchment. Typical pollutants above WHO recommendations included chromium, copper, zinc, arsenic, lead, mercury, and dioxin. On the urban River
Don in the 1970s, raw sewage contaminated foam from nondegradable detergent foam and was often blowing across the urban landscape (Anon, 1994; Barfield, 2001; Rotherham, 2008c).

\section{Ecology Reduced and Depleted}

The consequences of these changes for nature both within the rivers and across the wider landscape were disastrous. In the broad environment of the region, flora and fauna were reduced and transformed. This is apparent in records for the period but also from long-term longitudinal observations of ecology in the region (see for example, Shaw, 1972, 1974, 1976, 1978, 1981, 1988). Examples of the changes are presented in Table 1.

The overall changes in river ecology and the associated urban landscape were described by Shaw (1972, 1974, 1976, 1978, 1979, 1981, 1988), Gilbert (1989, 1992a,b), Bownes et al. (1991), Firth (1997), and Cartwright (2003). Some of the findings are summarised as follows. Pesticides and persecution combined to exterminate fish-eating river-birds such as grey heron (Ardea cinerea), kingfisher (Alcedo atthis), cormorant (Phalacrocorax carbo carbo), goosander (Mergus merganser), and red-breasted merganser (Mergus serrator). Carnivorous riverine mammals such as otter (Lutra lutra) were also lost due to pollution, persecution, and habitat destruction. As happened nationally, the ubiquitous non-native black rats (Rattus rattus), were displaced by the larger brown rat (Rattus norvegicus) during this same period; and by the 1970s, many riverside premises were ratinfested. Predators such as polecat (Mustela putorius) were 


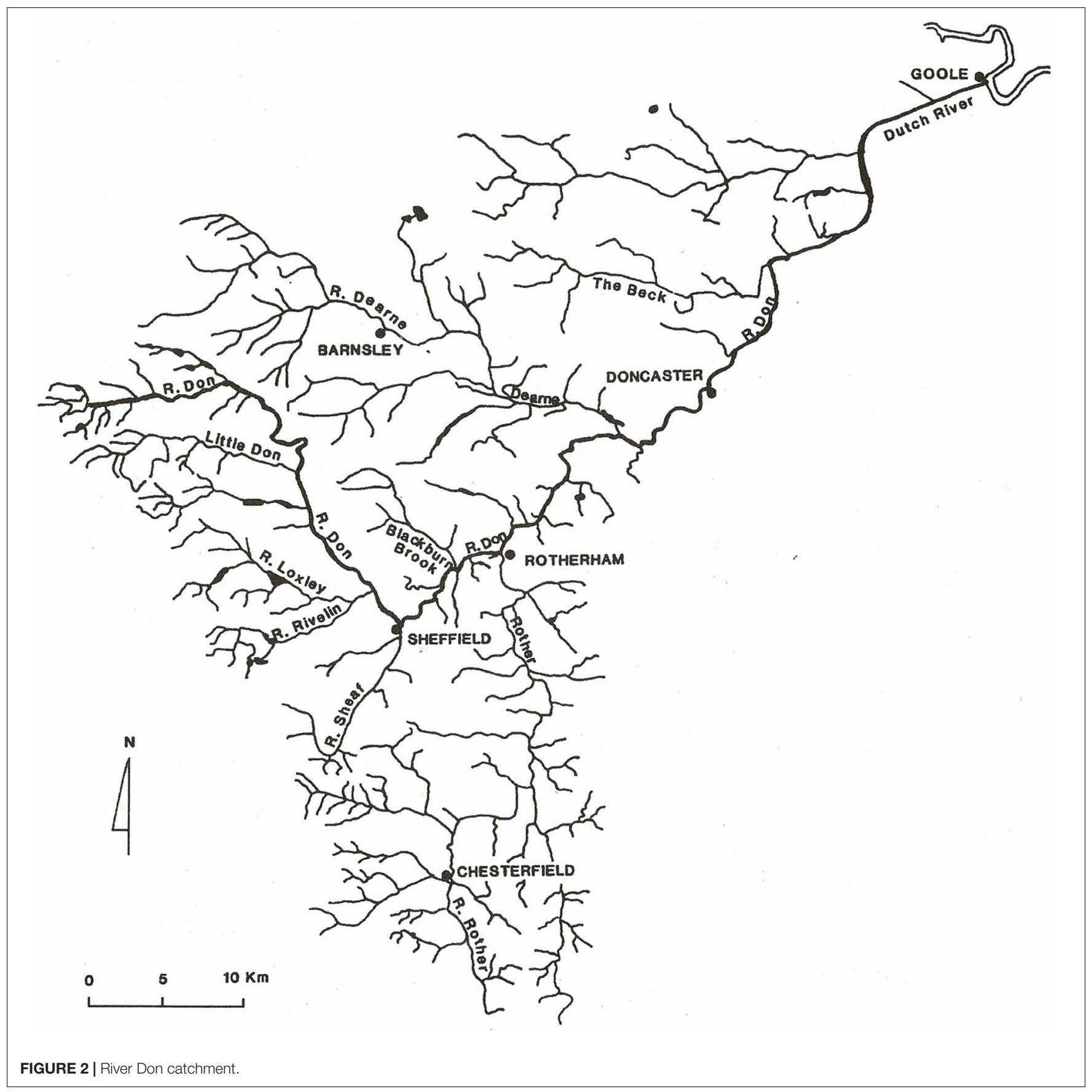

generally removed through deliberate persecution and badgers (Meles meles) were largely eradicated.

Riverside vegetation was mostly destroyed during the processes of urbanisation and associated canalisation of the watercourses, with some sections of rivers and streams culverted to run entirely underground. The aquatic vegetation within the urban rivers was entirely displaced by physical changes and by contaminated waters; and aquatic fauna such as invertebrates and fish was largely exterminated too. Associated with the demise of vegetation, invertebrates, and fish, there was the collapse of the entire food-web of ecology which depended on these. This situation was compounded by the removal and displacement of almost the entire original habitat along the rivers. This was the result of around 200 years of urbanisation and industrialisation in the emerging towns and cities, together with the intensification of agriculture and industry in the rural areas.

One very early impact of human utilisation of the rivers was the imposition of major constructed weirs to hold back a "head" of water to power the wheels of water-mills (Firth, 1997; Hey, 1998; Rotherham, 2018a; Figures 1, 2). This was probably begun as early as the eleventh century but occurred increasingly during the later middle ages and into the early industrial period 
TABLE 1 | Selected changes in fauna and flora across the wider region from the nineteenth century through to the twenty-first century.

Ecological and conservation attributes of the species

\section{Mammal extinctions and recoveries}

Otter

Decline and loss followed by recovery

Polecat

Decline and loss followed by recovery

Water vole Major decline in recent decades

Water shrew

Major decline in recent decades

\section{Bird extinctions and recoveries}

Kingfisher

Grey heron

Cormorant

Decline and loss followed by recovery

Goosander

Decline and loss followed by recovery

Decline and loss followed by recovery

\section{Fish extinctions and recoveries}

Atlantic Salmon

Decline and loss followed by recovery

Brown trout

Decline and loss followed by recovery

Common eel

Decline and loss followed by incipient recovery
Habitat loss and pollution followed by amelioration

Habitat loss, pollution, and persecution followed by amelioration and protection Habitat loss and competition from invasive species

Habitat loss and pollution

Habitat loss and pollution followed by amelioration

Habitat loss and pollution probably persecution followed by amelioration and protection

Habitat loss and pollution probably persecution followed by amelioration and protection

Habitat loss and pollution probably persecution followed by amelioration and protection

Habitat loss and pollution followed by amelioration

Habitat loss and pollution followed by amelioration

Habitat loss and pollution followed by amelioration and re-stocking

Habitat loss and pollution followed by amelioration and re-stocking

\section{Crustacean extinction}

Native or whiteclawed crayfish (Austropotamobius

Formerly widespread now virtually extinct

pallipes)

\section{Plant extinction and recovery}

River

water-crowfoot
Decline and loss followed by recovery
Reduced due to pollution and habitat loss and then aggressive competition and disease associated with signal crayfish invasion

Habitat loss and pollution followed by amelioration and re-stocking
A clean-water predator at the top of the food-chain and vulnerable to bio-accumulated toxins and to the demise of fish stocks. Until the 1950s the animal was also hunted in the wider catchment area.

Native carnivore eradicated by hunting and trapping by gamekeepers.

A clean water herbivorous species vulnerable to habitat loss and fragmentation through canalisation and culverting. Particularly vulnerable to predation by non-native mink and competition with non-native brown rats.

A clean water insectivorous species vulnerable to habitat loss and fragmentation through canalisation and culverting, and damage to food-chain through pollution.

Fish-eating bird affected by persistent pesticides and through widespread water pollution, the loss of its fish prey.

Fish-eating bird affected by persistent pesticides and through widespread water pollution, the loss of its fish prey. Also persecuted by gamekeepers, recreational anglers, water bailiffs managing fish-stocks, and others.

Fish-eating bird affected by persistent pesticides and through widespread water pollution, the loss of its fish prey. Also persecuted by gamekeepers, recreational anglers, water bailiffs managing fish-stocks, and others.

Fish-eating bird affected by persistent pesticides and through widespread water pollution, the loss of its fish prey. Also persecuted by gamekeepers, recreational anglers, water bailiffs managing fish-stocks, and others.

Insectivorous/carnivorous aquatic bird affected by water quality impacting on its insect prey. It seems that twentieth-century acid rain in particular affected water $\mathrm{pH}$ and may have had a critical effect on aquatic insect larvae.

Migratory fish sensitive to lowered oxygen levels in river systems and also critically affected by weirs to harvest water for water wheels which formed insurmountable physical barriers to movement. Also, affecting salmon was the diversion of the lower River Don at Fishlake near Doncaster from flowing south to the River Trent, and instead, northwards to the River Ouse and the Humber.

Fish species sensitive to lowered oxygen levels in river systems and also critically affected by weirs to harvest water for water wheels which formed insurmountable physical barriers to movement. May be affected by competition from introduced non-native trout species such as rainbow trout (Oncorhynchus mykiss) much favoured by anglers.

Migratory fish sensitive to lowered oxygen levels in river systems and also critically affected by weirs to harvest water for water wheels which formed insurmountable physical barriers to movement. Also, affecting salmon was the diversion of the lower River Don at Fishlake near Doncaster from flowing south to the River Trent, and instead, northwards to the River Ouse and the Humber. Probably affect by drainage of the extensive Yorkshire fenlands in the 1600s and 1700s, and by subsequent losses of riverside marshes and swamps.

Native crustacean affected by both disease and the aggressively competitive North American signal crayfish. Lost from many parts of the catchment due to chemical pollution.

Generally regarded as an indicator of good water quality it was lost from most areas and then re-populated by the Environment Agency. 
TABLE 1 | Continued

Ecological and conservation attributes of the species

This reintroduction no doubt also brought other clean-water fauna back to the Don catchment.

Butterbur

Decline and general loss from the urban rivers but visible in photographs at Niagara Weir in the early 1900s and recorded there by Shaw in 1981

Woodland flora Removal and then recolonisation

\section{Mammal invader non-native}

American mink

Major increase

Black rat

Colonisation, increase and then extinction

Brown rat

Colonisation and massive increase in population

\section{Crustacean invader non-native}

North American signal crayfish (Pacifastacus Now spread throughout the catchment and extending leniusculus) its range invasively

\section{Plant invader non-native}

Japanese knotweed Introduction and spread

\section{Giant knotweed} Introduction and spread

Himalayan balsam Introduction and spread

Mediterranean fig

Introduction via sewage and spread

Sycamore

Wall-associated flowers and ferns including non-native buddelia
Habitat loss and pollution A typical bankside species of less degraded rivers.
Loss to urbanisation and destruction of riverside woods followed by recolonisation under pseudo-woodland canopies particularly of Japanese knotweed

1970s release from fur-farms by animal rights activists

Increased throughout the middle ages but then displaced by its cousin the brown rat

Non-native coloniser which undoubtedly benefited from habitat creation through the industrial revolution

Deliberately introduced by fishermen and then spread invasively from the initial sites

Colonisation following removal of native competitors

Colonisation following removal of native competitors

Colonisation following removal of native competitors

Colonisation following removal of native competitors and thermal pollution of the waters

Colonisation following removal of native competitors

Almost complete absence of pollution-sensitive species such as most ferns followed by recovery as air pollution ameliorated and development provided abundant habitat availability
Species typical and characteristic of ancient woodland ground floras in this region and which demand shade, moisture. They mostly exhibit limited capability for dispersal but in these riverine systems are washed down stream with eroded bankside material from the upper catchment.

Non-native invasive carnivore which impacts greatly on the lower food-chain but may suffer competition from the larger mustelid, the native otter.

This was the rat species which carried the bubonic plague and thus had a major impact on the region. It subsequently became extinct as it was out-competed by the non-native, invasive brown rat. Brown rat numbers remain exceedingly high throughout the riverine urban area and they are abundant in the rural zone too. As an effective coloniser and competitor they drove the black rat to extinction and impact adversely on water vole numbers.

Non-native crustacean resistant to crayfish plague and aggressively competitive with native crayfish. Restricted in many parts of the catchment due to chemical pollution but as this has reduced the species has spread invasively. It may impact on the physical structures of ponds and rivers through its burrowing into banks.

Non-native plant brought in as a Victorian "wild garden" species and now widely invasive throughout the catchment but spreading only by rhizome fragments and not by seed.

Non-native plant brought in as a Victorian "wild garden" species and now widely invasive throughout the catchment but spreading only by rhizome fragments and not by seed. Much less common than Japanese knotweed.

Non-native plant brought in as a Victorian "wild garden" species and now widely invasive throughout the catchment spreading by explosive seeds deliberately dispersed by the public, by anglers, and by bee-keepers.

A notable historic marker of the heat pollution during the industrial revolution and as such is specially protected in Sheffield as "industrial heritage."

Non-native spreading widely during the twentieth century with wind-dispersed seeds and tolerant of air pollution.

Many of these species are capable of surviving in refugia within the wider region in the upper (less polluted) parts of the catchment and where narrow streamsides with rocky outcrops provide suitable habitats. With wind-dispersed spores or seeds, these species can recolonise into the less polluted urban zone and onto anthropomorphic structures such as masonry of walls and bridges. Mortar provides amelioration of acidic conditions for these largely calcicolous plants. Buddleia davidii arrived in Britain in the 1890s, but was not invasive in Sheffield until the 1980s/1990s when it morphed from an interestingly collectible garden shrub into a widespread coloniser of bare disturbed ground and masonry.

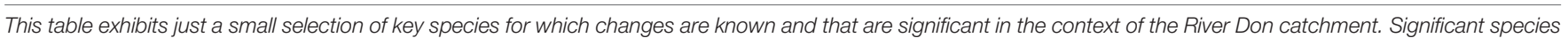
lost from the area at a very early date include wildcat (Felix sylvestris), Eurasian beaver (Castor fiber), and wild boar (Sus scrofa), and all these were ecologically significant. Data in the table are from on-going studies of the catchment as described and referenced in the text. 


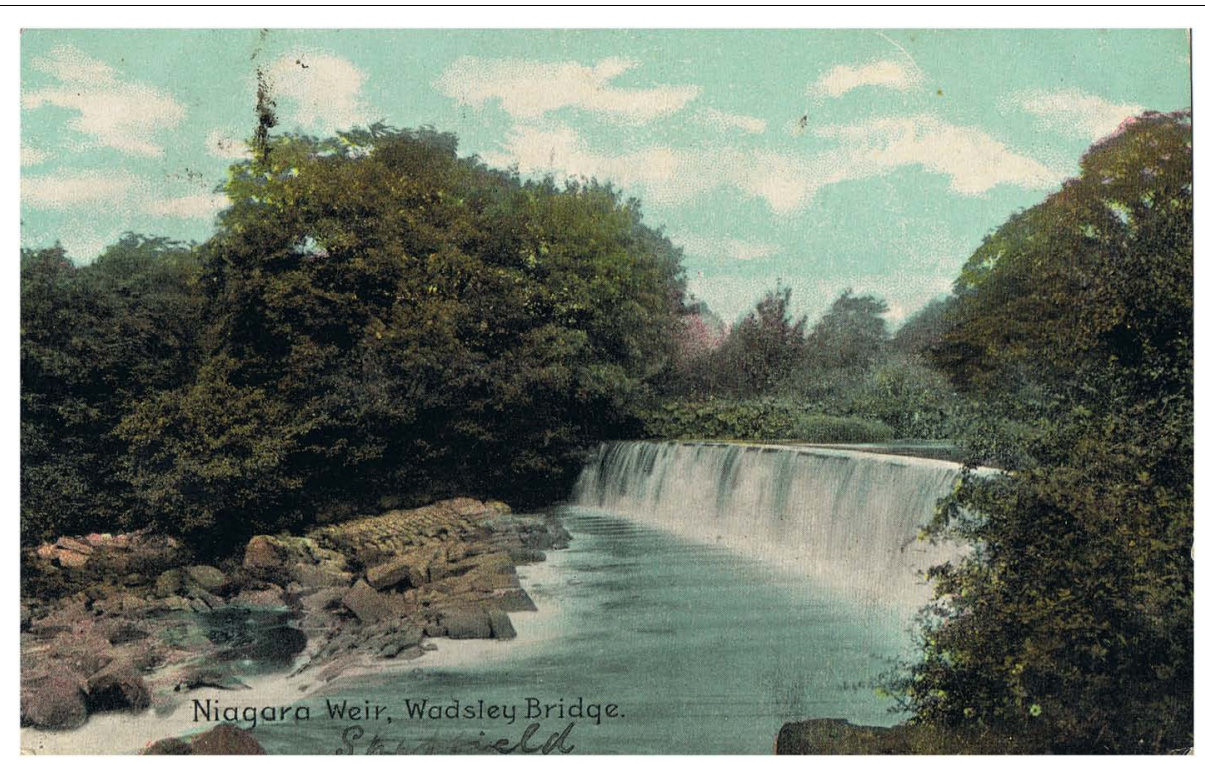

FIGURE 3 | Niagara Weir at Wadsley Bridge in the early 1900s and showing a good stand of the native riverside herb, butterbur (Petasites hybridus).

(Crossley, 1989; Rotherham, 2018a). As well as holding back water and altering flow regimes, the weirs became a major obstacle for migrating fish such as salmon (Salmo salar), sea trout (Salmo trutta), and common eel (Anguilla anguilla). The biomass of migrating eels was remarkable and sometimes sufficient to stop medieval water-wheels from turning (Rotherham, 2010, 2013b). It may be that salmon were still present in numbers even in the mid-1800s. This is suggested by for example, an apprenticeship agreement of 1850 (quoted by McClarence, 1988) from works at Salmon Pastures on the River Don, and which commented on the terms of employment in the contract that, "Masters should not compel the lad to eat salmon more than twice per week." Sadly, it is generally acknowledged that whilst a nice story, this is a long-standing, widely occurring urban myth.

However, this situation was not to persist for long as this extract from Anon (1897) (in Hey, 1998) shows:

\footnotetext{
"The narrow streets rise and fall in the most irregular manner. A thick pulverous haze is spread over the city, which the sun even in the dog days is unable to penetrate, save by a lurid glaze, and which has the effect of imparting to the green hills and golden com fields in the high distance the ghostly appearance of being whitened as with snow. The three rivers sluggishly flowing through the town are made the conduits of all imaginable filth, and at one particular spot. positively run blood. These rivers. are polluted with dirt, dust, dung, and carrion, the embankments are ragged and ruined; here and there overhung with privies; and often the site of ash and offal heap-most desolate and sickening objects. Sheffield. is a town where authority is so divided. that virtually there is no authority at all."
}

The state of the river is apparent from illustrations such as Figures 3-5, of a forge and a weir on the River Don in the early 1900 s.

The dire condition of the River Dearne was described by Rosenthal (2014), and the Rother together with its tributary the Doe Lea became synonymous with horrendous levels of pollution (e.g., Anon, 1988, 1994, 1995; Edwards, 1996). By around 1900 the urban rivers were in effect biologically dead (Orwell, 1937; Firth, 1997; Amishah and Cowx, 2000; Rotherham, 2014b, 2018a).

This situation was illustrated very starkly by the debates in the 1990s about the state of the River Rother which was now biologically sterile from south of Chesterfield where its component streams the Rother and the River Doe Lea both arise, to its northern confluence with River Don at Rotherham. Along with the publication of "The Poison Factory-the story of Coalite Chemicals" in 1994, long-term research on the Rother and Don (Rotherham, 2008c) revealed hot-spots of intense chemical pollution. These were found along both the riverbanks and in the river sediments. Whilst the 1994 Greenpeace volume "The Poison Factory" was highly political in nature, the scientific studies provided hard evidence of highly toxic contamination. Indeed, "slugs" of contaminated sediments where shown to be moving downstream over several decades (Figure 6). This presents a graphically descriptive image of the levels of metal pollutants and how they are moving and breaking up over the period of study. The density of polluting industrial activities and sites by the late 1900s is demonstrated by Figure 7 simply to provide some broad context to the wider catchment scenario.

The contamination plume identified in 1988 at Staveley divided into two smaller plumes at Hague and below Beighton (both recorded in 1995). By the early 2000s, these two smaller plumes were migrating downstream with one around Renishaw and the other between Beighton and Catcliffe. These massive occurrences of toxic chemicals were flowing through productive dairy farmland, through highly populated urban areas, and even through the region's biggest country park at Rother Valley. The situation became hugely embarrassing to government agencies, to industry, and to local politicians; and major worry for local residents (Anon, 1988). 


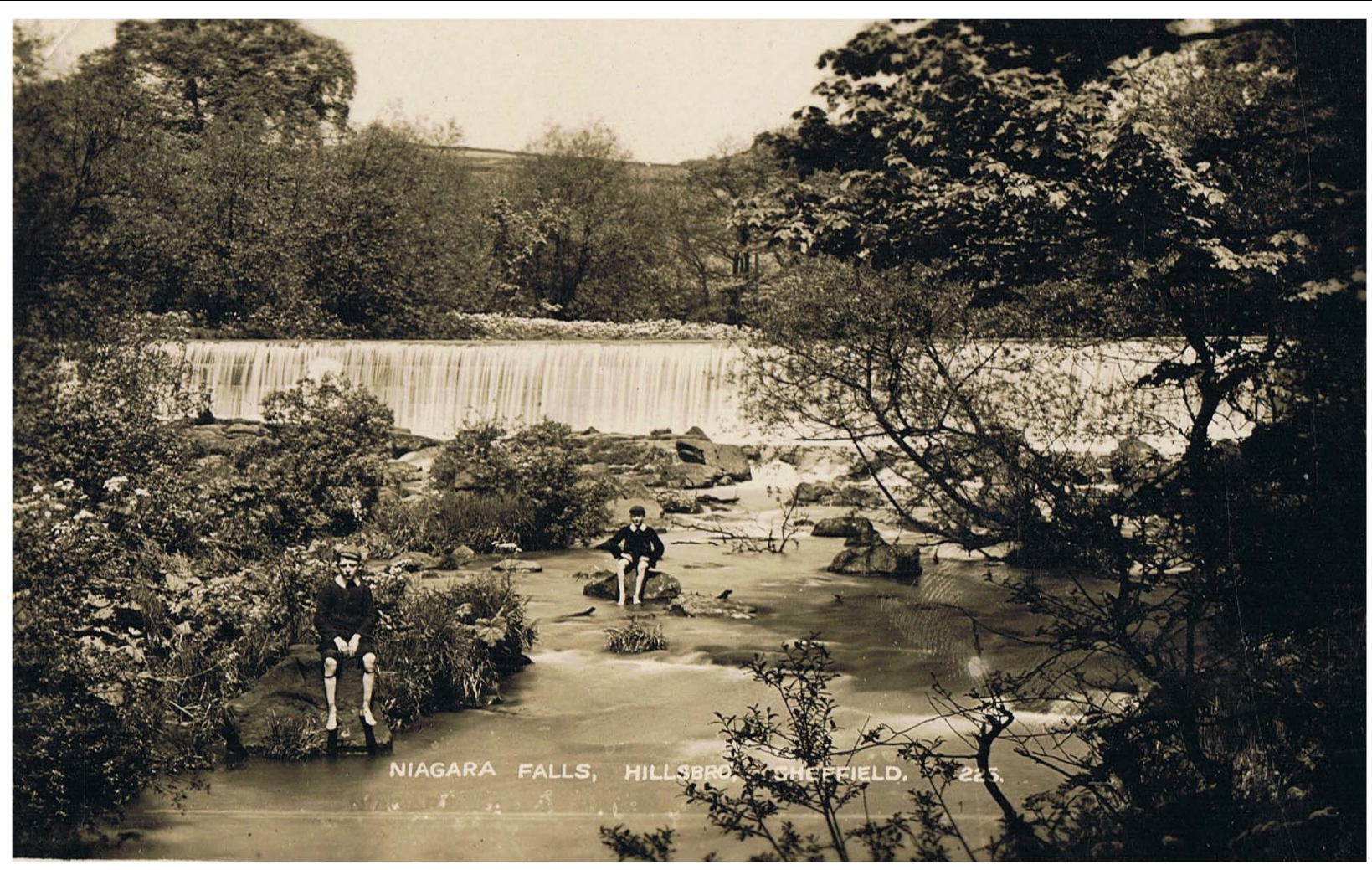

FIGURE 4 | Niagara Weir at Wadsley Bridge in the 1930s with a still rural landscape in the background but the butterbur reduced.

Other evidence of the scale of pollution has come from numerous studies undertaken over the period though much of this is still to be formally compiled and reported on. For instance, a small sphagnum bog recorded at Tinsley Park but subsequently lost to opencast coal-mining had lead $(\mathrm{Pb})$ present at $827 \mathrm{mg} \mathrm{kg}^{-1}$ in its peat-core. The site adjacent was grossly contaminated by metallic waste from several hundred years of intensive metal manufacture. Some further information is provided in Rotherham (2008c), but much is as yet unpublished. Other studies for example, have also been undertaken along parts of the River Sheaf catchment before it too merges with the River Don in Sheffield centre. Indeed, in the western suburbs of Sheffield crude lead ore can still be found in the riverbed and lead is detectable in soils at elevated levels as a consequence of medieval lead smelting on local "bole-hills."

\section{Recolonisation and Recovery}

From a low point in the 1970s, there began a slow recovery of ecological function which gathered pace during the 1980s and 1990s. Post-1950s closure of factories due to the massive and abrupt economic decline in British manufacturing (Warman, 1969), combined with legislation which enforced compliance with improved pollution controls (Rotherham, 2017c, 2018a) to reduce pollution. The result was that at long last, the environmental decline was slowed, halted, and then in part reversed. Rivers across the region were increasingly recognised for planning purposes as important "green corridors" for people and for nature (Bownes et al., 1991; Gilbert, 1992a; Griffiths et al., 1996). Additionally, some green spaces close to the rivers were acquired as nature reserves and others were protected as potential floodwater control sites. Public walkways along the rivers also added to the impetus to improve environmental quality as did conversion of sites from former heavy industrial use to retail, leisure, sports, and entertainment. Associated with these changes there was major re-shaping of both infrastructure and landscape in Sheffield's industrial Don Valley to create a green backdrop to the post-industrial renaissance.

Recolonisation by nature of these urban riverscapes began during the 1970s and was documented in part by the local natural history society (Shaw, 1972, 1974, 1976, 1978, 1981, 1988). This work was then followed up by a series of surveys during the 1980s and 1990s, by pioneering urban ecologist Gilbert $(1989,1992 a)$ and for the Sheffield City Ecology Unit (Rotherham, 1986, 1987; Wild and Gilbert, 1988; Bownes et al., 1991; Rotherham and Cartwright, 2000, 2006). A mix of local industrialists, conservationists and natural historians with an emerging "urban wildlife movement," joined with government agencies and local anglers to call for change (Griffiths, 1989). These demands triggered the present-day ecological renaissance and on-going long-term observations and monitoring are used to assess the changing ecological dynamics of this now recombinant system (Clarkson and Garland, 1988; Rotherham, 2017a).

During the 1990s and the early 2000s, the Environment Agency which had taken over water quality and fish conservation 


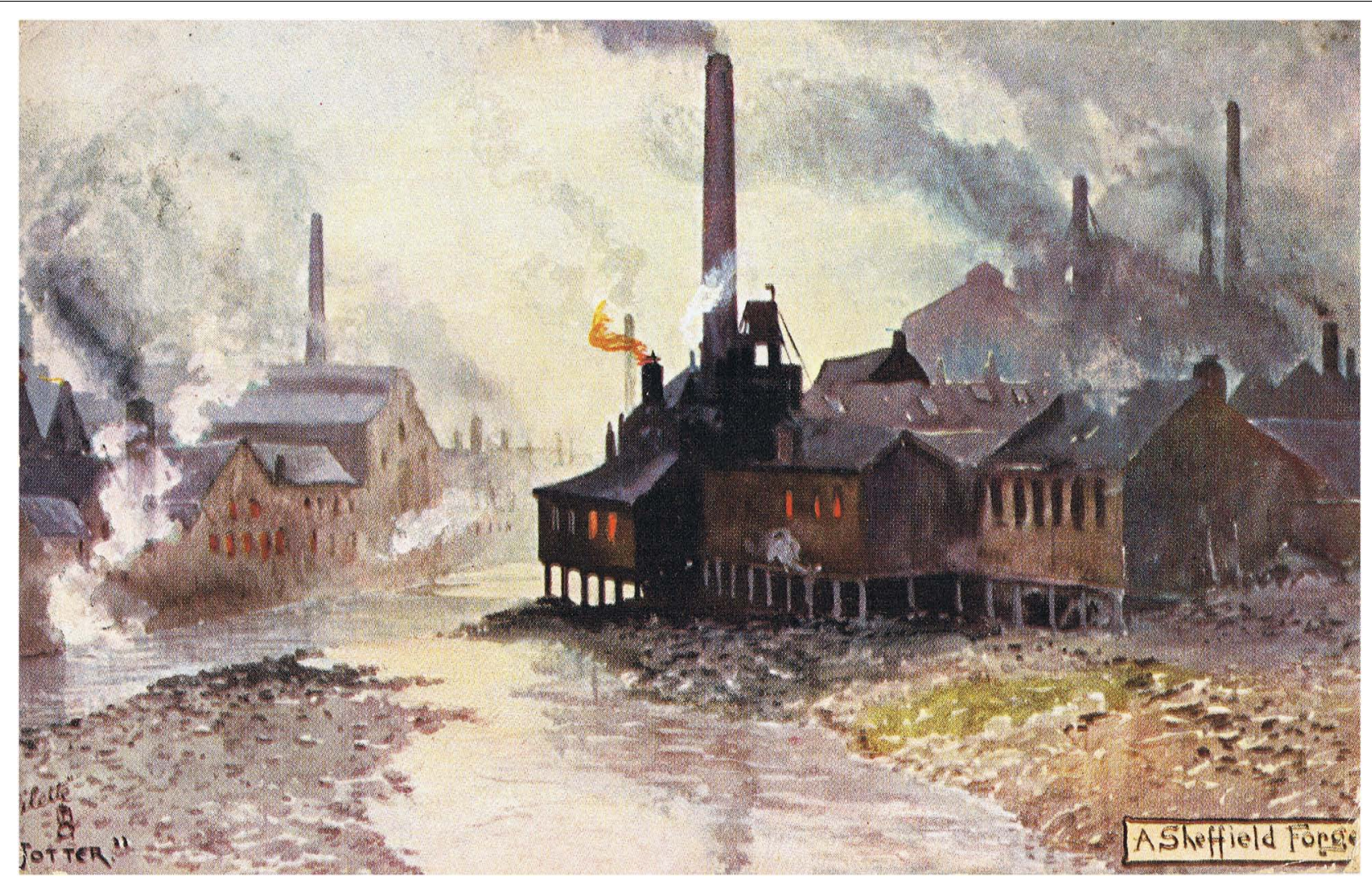

FIGURE 5 | A Sheffield forge on the River Don, 1907.

duties from the former National Rivers Authority, began a series of introductions of both aquatic river vegetation such as river water-crowfoot (Ranunculus fluitans) (Firth, 1997, 2018; Amishah and Cowx, 2000) and of fish stocks. These interventions went alongside the natural processes of recolonisation which were already underway. However, the ecological recovery did not represent a return to the former state of the river ecology but the development of a new "hybrid" or recombinant ecology. Both native and non-native species (many garden escapees) have colonised into the vacant niche now represented by the recovering river systems. As observed by Gilbert (1992a) surveying the River Don in the 1980s, this was not a case of invasive non-native species displacing the natives, but both native and non-native fauna and flora recolonising a vacant space. Within 20-30 years, extensive tracts of riverbank, of riverside built structures such as walls, and in-stream shinglebanks and islands, had colonised with native trees such as alder (Alnus glutinosa), willow sp. (Salix spp.), birch (Betula spp.), ash (Fraxinus excelsior), and non-native trees like sycamore (Acer pseudoplatanus) and shrubs particularly buddleia (Buddleia davidii). The riverbank walls also have exotic cultivars of ivy (Hedera spp.), Russian vine (Fallopia baldschuanica), great bindweed (Calystegia silvatica), and in recent years wild clematis (Clematis vitalba). There are also quite extensive areas of Mediterranean fig (Ficus carica) (Gilbert, 1989, 1992a; Bownes et al., 1991; Rotherham, 2018a).
The riverbank and shingle areas have dense stands of bramble (Rubus fruticosus agg.), nettle (Urtica dioica), willowherbs (Epilobium spp.), thistles (Cirsium spp.), broad-leaved dock (Rumex obtusifolius), great flote-grass (Glyceria fluitans), canary reed-grass (Phalaris arundinacea), and dominant patches of Japanese knotweed (Reynoutria japonica), Himalayan balsam (Impatiens glandulifera), and giant hogweed (Heracleum mantegazzianum). These species tend to form the dominant communities with a wide range of associates depending on the degree of disturbance, the nature of the substrate and river debris, and the degree to which the riverside vegetation has still-water and therefore plants such as meadowsweet (Filipendula ulmaria), marsh marigold (Caltha palustris), common valerian (Valeriana officinalis), and reedmace (Typha latifolia) for example. Within the river channel the vegetation is strongly influenced by the degree of shelter from or exposure to the erosive and depositional forces of flood-waters. Proximity above or below major weirs also influences substrates and vegetation. Deposits along the riverbanks that are drier and more stable may have dominant bracken (Pteridium aquilinum).

Long stretches of the urban rivers are still constrained by walls built of either bricks or concrete (Rotherham, 2008c). Until the early 1980s, even where the substrates were calcium-rich mortar between bricks or else concrete, there were relatively few flowering plants or ferns growing on them. The combination of gross acid-rain and deposition of soot and grit had eliminated 


\section{Example of the downstream migration of mercury conta minant plume along the River Rother catchment (from Rotherham, 2008a) from work with Frank Spode and Badria Ahmed}

Tupton
Whittington 1
Whittington 2

\section{River \\ Rother}

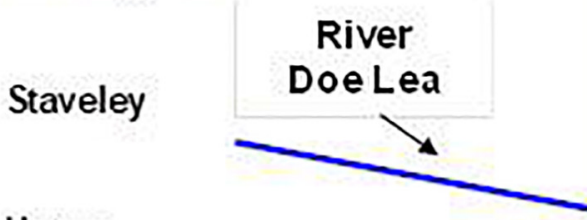

Hague

Renishaw

Beighton

Beighton

Beighton

Rotherham

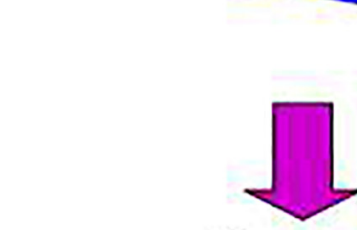

Don 2 - Don 1

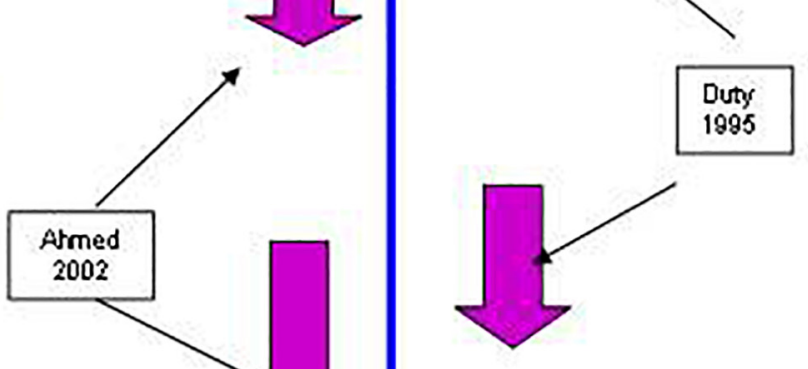

\section{River Don}

FIGURE 6 | Migration of mercury contamination on the River Rother.

almost everything. A study for the then Sorby Scientific Society (Hugill and Blacktin, 1929; Hugill, 1929) measured the amount of acidic dust and grit falling on parts of the urban catchment and demonstrated an air-pollution input of around five to seven tons of grime per square mile per week in the mid-1920s. These figures were in the Sheaf Valley and west of the city centre. The urban Don Valley was undoubtedly higher. On-going professional monitoring (e.g., Anon, 1986) has shown the gradual improvement in air quality and this followed the Clean Air Acts of the 1950s and 1960s and the subsequent imposition of clean air "Smokeless Zones" (Warman, 1969). Ecological impacts of environmental deterioration can be demonstrated in many and varied ways. In the polluted heartlands for example, the pollution-tolerant lichen Lecanora conizaeoides was ubiquitous but almost the only lichen species to be found. Now, with cleaner air and less acidity this lichen has become far less abundant and other more sensitive species have colonised. 


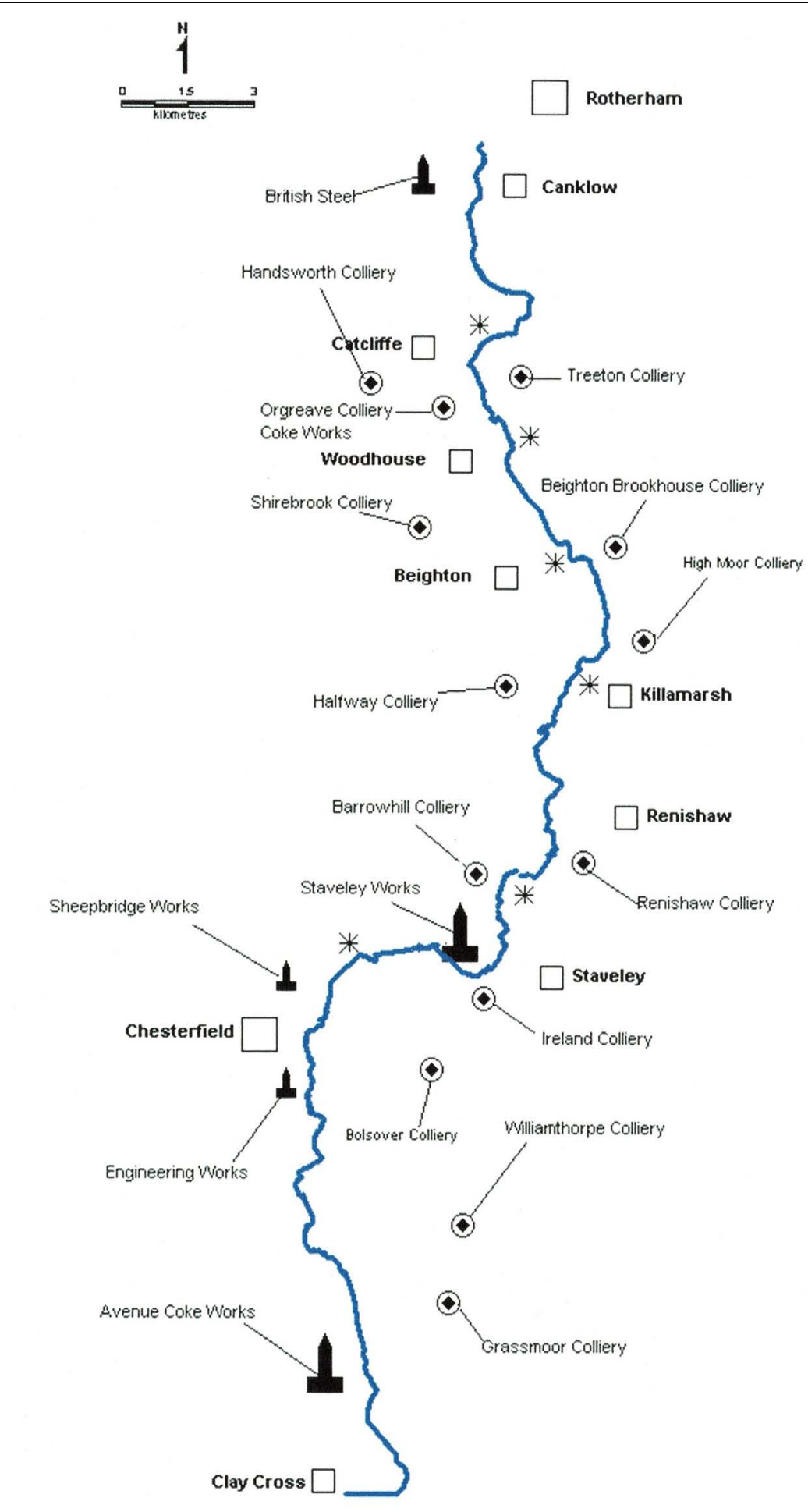

Crown copyright Ordnance Survey. in Edina Digimap / JISC supplied service.

\begin{tabular}{|l|}
\hline 1 Mill \\
Calliery \\
* Sewage works \\
\hline
\end{tabular}

FIGURE 7 | Sources of pollution along the River Rother. 


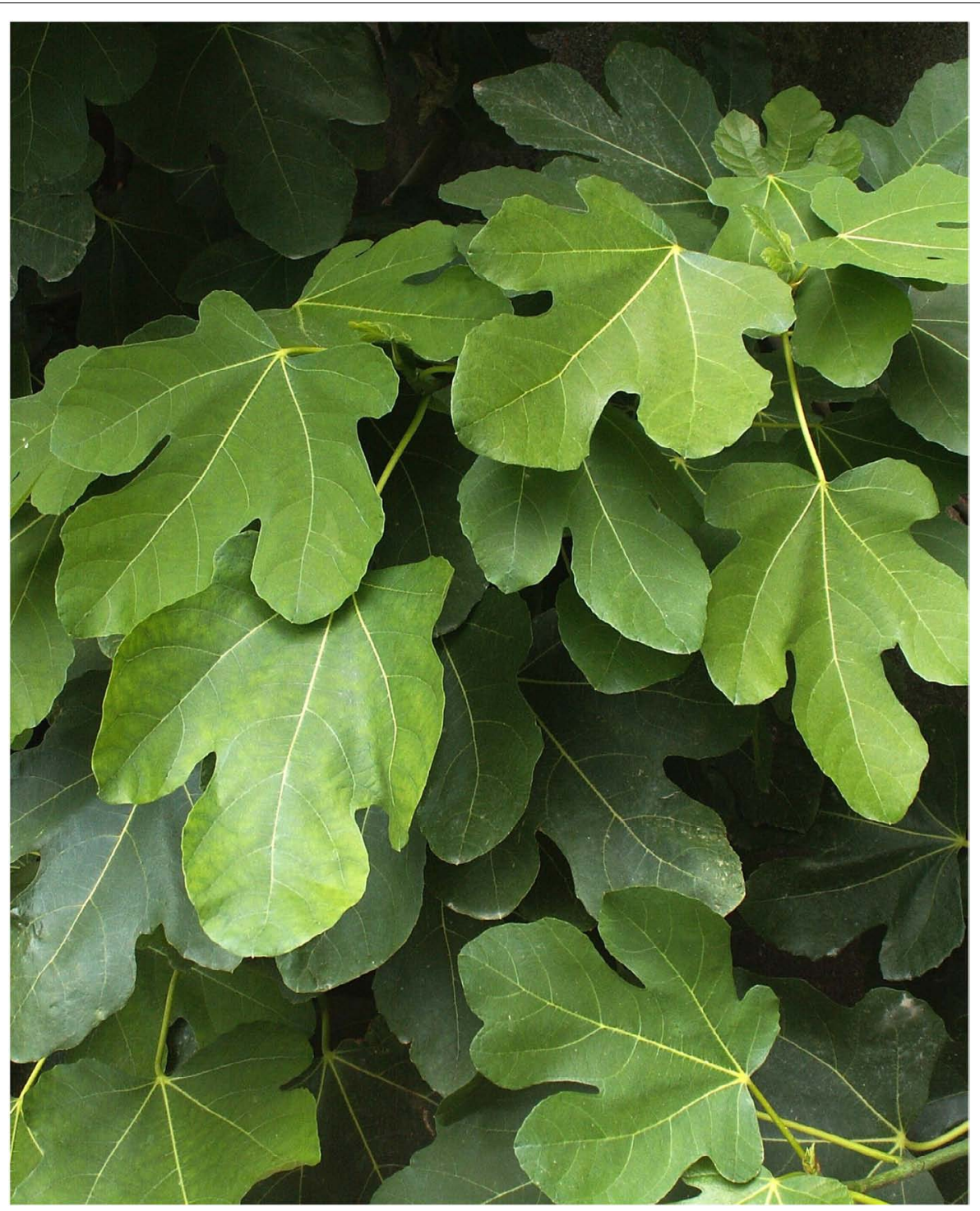

FIGURE 8 | Mediterranean Fig - a non-native plant that spread due to industrial warming of the river-water and now specially protected in Sheffield as "industrial heritage."

Acid rain and grit deposition also eradicated most epilithic plants and especially sensitive fern species. Following the amelioration of air quality in recent decades, there has been a rapid increase in diversity of wall-dwelling vegetation both ferns and flowering plants. Native species such as wall lettuce (Lactuca muralis) have colonised alongside nonnatives such as red valerian (Centranthus ruber), ivy-leaved toadflax (Cymbalaria muralis), yellow corydalis (Corydalis lutea), and most recently (first recorded in 2005), Mexican daisy (Erigeron karvinskianus). Fern species have also returned in significant numbers with species such as wall rue (Asplenium ruta-muraria), maidenhair spleenwort (Asplenium trichomanes), black spleenwort (Asplenium adiantum-nigrum), hart's-tongue (Asplenium scolopendrium), and male fern (Dryopteris filix-mas), frequent along most of the retaining walls.
Hart's-tongue was occasionally recorded by Shaw in the 1970s and 1980s surveys.

The effects of acid rain were also visible in terms of changed flora of both grasslands and woodlands, and some of the impacts still persist. Confirmed by the records of Jonathan Salt in the 1700s, there is evidence of calcicolous plants close in to the city centre but these have long since been eradicated and replaced by calcifuge species. Some local ancient woods have a ground flora now dominated by heather (Calluna vulgaris), bilberry (Vaccinium myrtillus), and wavy hair-grass (Deschampsia flexuosa) rather than a typical mix of woodland flowers. With skeletal soils eroded and leached of nutrients this is a long-term shift. In some cases these sites look at first sight to be woodlands regenerating on former heaths, but the historic archives and site archaeology 


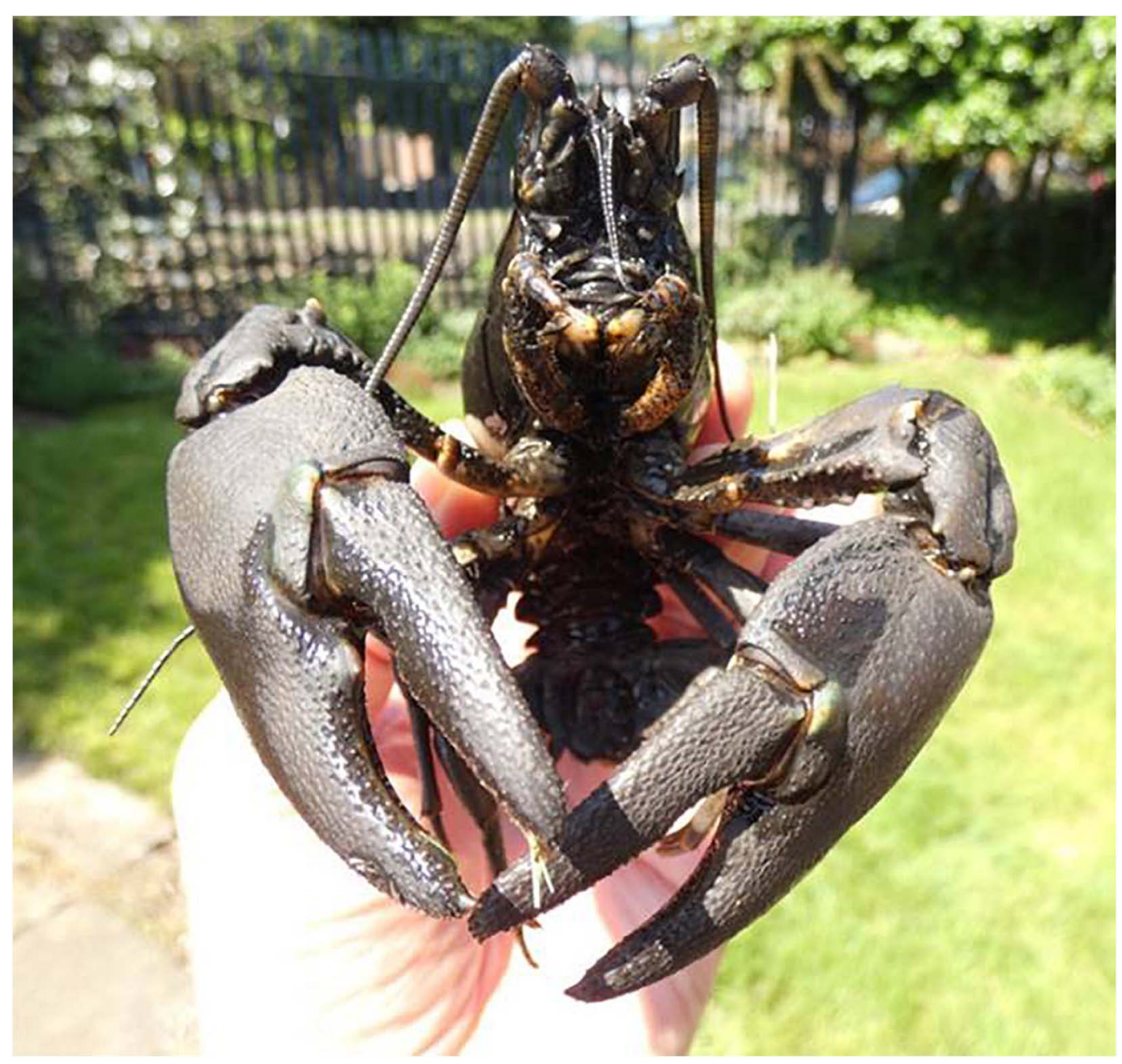

FIGURE 9 | American signal crayfish from the River Sheaf.

confirm that they are ancient woods where the soil has become heavily acidified.

\section{Riverine Dispersal}

Whilst some species move along the river system as an ecological corridor and may travel upstream or downstream accordingly, others disperse downstream on water-currents. Mammals such as otter and mink for instance, move along the corridor irrespective of current and may travel short distances overland if necessary. On the other hand, invasive plant species such as giant hogweed, Himalayan balsam, and Japanese knotweed, are invariably carried downstream with the current. This begs the question then of how these species move into the upper catchment and the answer is by deliberate human intervention and accidental release (Rotherham, 2005a,b, 2011a). Himalayan balsam for example is spread between the head-water rivers of the catchment by coarse fishermen who use the seeds as ground-bait, and by balsam enthusiasts who simply like to spread the plant as widely as possible (Rotherham, 2001a, 2005a). The latter include gardeners and bee-keepers that disperse balsam seeds to generate a source of pollen and nectar for honeybees.

Extensive surveys of plant records and history have shown how balsam spread around the region afters its first reported feral occurrences in the late 1800s. Similarly, giant hogweed can be traced back to large houses and their gardens, or estates in the $1800 \mathrm{~s}$, often in the upper reaches of river catchments. The plant was grown as a spectacular "wild garden" specimen alongside balsam, giant knotweed (Fallopia sachalinensis), Portuguese laurel (Prunus lusitanica), rhododendron (Rhododendron ponticum), and similar exotics. By the mid-1900s, these plants were escaping from collections and becoming naturalised. Propagules readily disperse downstream as floating seeds (balsam and hogweed) or root fragments (knotweed) (Rotherham, 2011a).

\section{Native Woodland Flora in a Recombinant Community}

One of the remarkable discoveries or observations made by Gilbert and myself in the 1980s and 1990s was the recolonisation 
of the now improved urban rivers by indicator plants of ancient woodlands. For the first time since initial surveys of plants along the riverbanks by the Sorby Natural History Society in the 1970 s (Shaw, 1972, 1974, 1976, 1978, 1981, 1988), there were detailed vegetation assessments along the River Don. Gilbert mapped the dominant stands of vegetation along both the urban River Don and the Sheffield and Tinsley Canal (Wild and Gilbert, 1988; Gilbert, 1989, 1992a). This exercise involved mapping the exact locations of dominant plants onto large-scale maps by hand. In part this was an exercise to map the invasive non-native plants particularly Himalayan balsam and Japanese knotweed. He and the survey team also recorded the wild figs as previously observed by Margaret Shaw (1988), and then followed-up along all the urban rivers by my own survey team at the Sheffield City Ecology Unit (Bownes et al., 1991).

Gilbert (1989, 1992a) observed some of these changes with colonisation of the urban River Don by non-native sycamore, Himalayan balsam and Japanese knotweed into a vacant niche created by gross pollution and disruption. The new communities he suggested, were "appropriate and distinctive" for an urban area. In the course of these vegetation surveys it was noticed that underneath the dense stands of balsam and knotweed there was a "woodland" flora of native flowers typical of "ancient woods." These dense riverside canopies of invasive, non-native plants were acquiring woodland groundfloor species by dispersal and colonisation downstream with evidence of diversification under a pseudo-woodland canopy. It seemed that species such as bluebell (Hyacinthoides non-scripta), wood anemone (Anemone nemorosa), greater woodrush (Luzula sylvatica), greater stitchwort (Stellaria holostea), dog's mercury (Mercurialis perennis), pendulous sedge (Carex pendula), yellow archangel (Lamiastrum galeobdolon) and more, are washed down as seed of plant fragments from riverine woodlands upstream. Some of this was published by Gilbert (1989, 1992a). Today, alongside these natives there are non-native species such as hybrid bluebell (Hyacinthoides non-scripta $\times$ hispanica), variegated yellow archangel (Lamiastrum galeobdolon subsp. argentatum), monkey flower (Mimulus guttatus), and montbretia (Crocosmia $\times$ crocosmiiflora). The dense stands of monoculture knotweed cast a dense shade from midsummer onward, but as in ancient woodland, the vernal or spring flowers thrive before the canopy closes. Summer shade then eliminates from the sward potential competitors which would otherwise out-compete the woodland flowers. The result is pseudo-woodland ground floras under exotic canopies. Recent observations indicate that this process continues as flood-waters disperse ancient woodland flora and non-native invaders alike.

\section{Mediterranean Figs as a Marker of the Industrial Revolution}

It still comes as a great surprise to many local people that we have wild Mediterranean fig-trees along these urban rivers (Figure 6). These originated mostly from the time of heavy industry in Sheffield when river-water was used to cool the works causing streams to run at $20-23^{\circ} \mathrm{C}$ summer and winter. This increase in prevailing temperature throughout the riverine "heat island" allowed exotic plants to thrive along the still heavily polluted watercourses. Mediterranean fig (Ficus carica) was perhaps the most dramatic coloniser which arrived in local food products such as the ubiquitous "fig biscuits." Essentially the seeds pass though the human gut undamaged and end-up in the sewage system and at that time this often discharged directly into local rivers and streams. Even today some rivers have "stormwater overflows" where raw sewage passes into the stream at times of flood. With the warm micro-climate, fig-seeds deposited in river-bed silts or in crevices in the walls of canalised streams germinated to grow wild figs. Mostly originating from the mid-1800s to the mid-1900s, associated with gross industrial pollution, the plants potentially grow into quite large, multisuckered figs. Younger plants still arise along all the urban rivers and more widely figs are now available from garden centres and popular to grow as garden plants. Some of these or their progeny escape into the wild, and seeds from discarded food products, aided by warmer climate, also colonise.

The Sheffield fig-trees Figure $\mathbf{8}$ were noted by local industrialist and amateur naturalist Richard Doncaster when he found them on the River Don near his steelworks at Owlerton. He alerted his friend, local botanist Margaret Shaw and she confirmed the identification. Richard and Margaret then led the Sorby Natural History Society's botanists on a series of surveys of the urban River Don and a good number of trees were located (Shaw, 1972, 1974, 1976, 1978, 1981, 1988; Gilbert, 1989, 1992a). Dr. Oliver Gilbert, then Sheffield University's pioneering urban ecologist, undertook detailed surveys and carried out experimental work to show that seedlings were still produced from the sewage-contaminated river-silts. It was Oliver's insight that highlighted the role of pollution and temperature in the emergence of Sheffield's riverine fig forest. Following these surveys, the "Sheffield Nature Conservation Strategy" (Bownes et al., 1991) included the wild fig as a protected species in Sheffield. This was an eco-cultural marker of the Industrial Revolution and considered as significant as the ancient built archaeology of weirs, water-wheels, and mills. This is the only specially-protected "alien" plant species in Britain; and they do produce fruit. Whilst the main wild sites for figs are along the River Don, it does occur elsewhere. There are large plants in the Lower Don Valley with a now-famous "fig forest" near the Meadowhall Shopping Centre. Visitors still come from as far away as the United States to see this. They also occur on the Sheffield and Tinsley Canal, along the Porter Brook and the River Sheaf and young plants still establish.

\section{Otter, Mink, and Water Vole}

The local rivers hold populations of now rare mammals such as water vole (Arvicola amphibius), water shrew (Neomys fodiens), and otter. The latter became extinct in the region due to the changes described but by the early 2000s were reappearing in the wider catchments of the Rother and the Don. In 2005, otter were observed on the River Don in the urban centre of Sheffield and since then have been present in low numbers along the entirety of the Don and Rother. Interestingly in terms of the recombinant ecology of this emerging urban river system, the otters were making use of dense knotweed stands as cover. It is already noted that otters make preferential use of dense Rhododendron 
ponticum for lying up and for holt-sites (Rotherham, 1983, 2001b). In the period between the regional extinction of otter and its recovery in the early millennium, the invasive American alien, mink (Neovison vison) had dispersed into the Don catchment. This provides an example of a non-native invader contributing to the decline of a native mammal, the water vole. The impact was undoubtedly compounded by habitat loss and simplification with removal of riverbank diversity, vegetation, and importantly smaller side-channels and tributaries, through canalisation of the urban rivers. This meant efficient predation of voles by mink with few safe refuges from which recolonisation could take place. However, within the recombinant ecological system other factors certainly came into play as increasing populations of another non-native mammal, brown rat, competed with voles for territory and displaced them. However, the return of native otter will impact on this situation through territorial competition with the smaller mink. The latter has a slight advantage through its more terrestrial behaviour and this may enable both species to coexist. Nevertheless, it is likely that the mink population will reduce as otter numbers rise. Whether vole numbers will continue to fall or maybe recover remains to be seen. However, in this recombinant system it may be that otter displacement of mink will trigger a water vole recovery. However, rising numbers of non-native brown rat (associated with climate warming and reduced public resources for pest control) might limit this.

\section{The Urban Deer}

Deer have been absent from most of the Don catchment since the demise of the former medieval deer parks across the region (Hey, 1998). However, along the ecological corridors of the Don and the Sheaf in particular there has been a recolonisation by three species of deer, two native and one non-native (Rotherham, 2001c, 2003; Rotherham and Derbyshire, 2012). Red deer (Cervus elaphus) have come downstream firstly on the Don from an escaped medieval herd higher up the catchment. More recently, since the 1980s, they have moved down the Sheaf Valley from a feral herd on the Peak District moors where the river and its tributaries rise. Native roe deer (Capreolus capreolus) have also recolonised and non-native muntjac (Muntiacus reevesi) are increasingly reported from the urban centre of Sheffield. In all these cases, the often wooded green corridors of the arterial rivers provide good habitat and excellent cover for these large mammals moving into and through the urban areas.

\section{Fish and Fish-Passes}

One major impact of human exploitation of the watercourses was the imposition of weirs and associated engineering structures all along the main rivers and their tributaries. These proved to be major barriers to migrating fish. However, now that the overall environmental conditions have improved and fish-stocks have been reintroduced, there has been a major programme of fishpass construction around the weirs. This investment has been remarkably successful and salmon returned to spawn in the upper reaches of the main rivers. This represents a remarkable turn-around in the rivers' ecological fortunes.

However, in terms of native, non-native, and recombinant ecologies of these watercourses, there a some key questions.
As well as appropriate native fish species reintroduced to the recovering rivers by the Environment Agency and partners, it is likely that many non-native fish have been introduced by enthusiasts. This is a topic which for now remains an unknown but it is certainly the case that exotic fish have been introduced by both anglers and simply by individuals with fish collections surplus to their needs. In such situations, the simplest expedient is to release the fish to a local pond or river. Other non-native fish introduced for sporting purposes include carp (e.g., Cyprinus carpio) in still waters such as the canals, local ponds, and reservoirs, and rainbow trout (Oncorhynchus mykiss) in rivers and streams.

\section{Riverine Bird Populations}

Most bird species associated with the urban rivers were displaced entirely due to physical changes and habitat loss, pollution of the water and associated destruction of aquatic vegetation and aquatic fauna, and particularly the loss of fish. Several species were also affected by wider pollution issues of chemicals such as DDT in the food-chain. Removal and degradation of riverine habitat affected most river-bird populations. Species lost included dipper (Cinclus cinclus), kingfisher, grey heron (Ardea cinerea), moorhen (Gallinula chloropus), coot (Fulica atra), grey wagtail (Motacilla cinerea), pied wagtail (Motacilla alba), sand martin (Riparia riparia), common sandpiper (Actitis hypoleucos), goosander, red-breasted merganser, cormorant, mute swan (Cygnus olor), and several duck species. The swift (Apus apus) is a distinctly urban species which breeds in buildings along the urban rivers and hawks insects over the waterways. It is singularly vulnerable to human-induced changes and in particular the modification or demolition of old buildings and may now be vulnerable to riverside post-industrial renaissance.

During the 1980s, a slow recovery in breeding and wintering bird populations began. This has continued through to the present day with a wide range of river-birds now present and both breeding and wintering in good numbers. The new avifauna is largely dominated by native species but with some nonnatives increasing rapidly. The two most obvious exotic bird species are mandarin duck (Aix galericulata) and Canada goose (Branta canadensis), and they are accompanied by greylag goose (Anser anser) which whilst native is a feral population. In the riverside buildings and on the taller canalised retaining walls, the exotic feral pigeon (Columba livia) is ubiquitous. Little owl (Athene noctua) also occurs and was a nineteenth-century import from France.

Birds of prey such as peregrine falcon (Falco peregrinus), sparrowhawk (Accipiter nisus), common buzzard (Buteo buteo), and red kite (Milvus milvus), were all lost from the region due to a mix of persecution, chemical pollution, and overall environmental degradation. The only species which survived by the 1970s was the ubiquitous kestrel (Falco tinnunculus). However, by the 2000s, all these species had returned to the region.

Also, with improved water quality, invertebrate populations re-established, and aquatic vegetation returned to the river, fish populations have recovered. Following these changes, many bird species have also recolonised. Whilst the physical disruption of 
the imposed brick and concrete walls which line much of the river-course has not been remediated, kingfishers for example have adapted and occupy artificial nest-sites in one-time drainpipes discharging from retention structures. Both sand martin and little owl also utilise artificial sites. The city environment around the rivers remains a typical urban "heat island" and in winter this draws afternoon gatherings of birds roosting overnight. In winter, hundreds of wagtails may be present in and around the rivers, and grey herons for instance, may number over twenty birds at an individual site.

\section{Crayfish as Aquatic Eco-Architect Species}

On-going surveys since the 1990s have recorded the demise of the native British crayfish (Austropotamobius pallipes) and the aggressive spread of the invasive alien, the North American signal crayfish (Pacifastacus leniusculus) (Figure 9). These are potentially very abundant invertebrates with rapid population growth and effective dispersal. Through their extensive burrowing into soft riverbanks they have a major impact on the river environment. They are aggressive predators but also potential prey items for both mink and otter. The relationship with river pollution is interesting since at the start of our research the alien was very restricted and the native hung on in isolated streams effectively protected from non-native invasion by the gross contamination of the main rivers. However, with ecological recovery along the major watercourses following reduced pollution, the entire river catchment is effectively joinedup for dispersal. A mixture of human-aided spread and natural dispersal means that the signal crayfish is now present in most parts of the catchment and in some sites such as millponds of former industrial sites is super-abundant with capture numbers exceeding 1,000 in a single day. Clearly, in the future recombinant ecology the signal crayfish will be an influential component and this has been facilitated in part at least by the improved water conditions.

Figure 10 presents a schematic summary of the processes and changes as generalised for the River Don catchment over a period of perhaps 200 years. The major ecological decline began in the late 1600 s and early 1700s, and recovery took place in the late 1900s and early 2000s. Examples of species-species interactions of native and non-native are exemplified by the native crayfish and the signal crayfish, and the American mink and otter, both described earlier. In the emerging recombinant ecosystem, the native crayfish was initially protected from its more competitive cousin in safe enclaves that were cut-off by gross water pollution. Lowering of pollution levels has allowed the signal crayfish to spread and the native species is now probably extinct. The native water vole was sent into major decline firstly by habitat loss and environmental degradation and then by a mix of predation by non-native mink and probably competition from longestablished non-native brown rat. However, the mink population is now declining as the native otter, is re-colonising having initially been removed by pollution and habitat degradation. A question remains as to whether this decline in mink will allow re-establishment of water vole. Furthermore, might predation of signal crayfish by otters help re-open a niche for native crayfish to 1 day return?

\section{CONCLUSION-RECONNECTING THE ECOLOGY AND THE LANDSCAPE}

The history of the River Don and its catchment shows a remarkable decline in environmental quality and associated biodiversity over a period of perhaps a 1,000 years from the inception of early industrial development to the post-industrial recovery. However, in the last 50 years the river and its environs have begun a phase of recovery and some of this has been dramatic and indeed speedy. Nevertheless, the recovery of ecology does not necessarily equate with a return to natural processes or a renaturalisation of catchment functions. This situation was thrown into stark reality by the 2007 floods in Sheffield and across South Yorkshire when the entire city centre was cut-off by the inundation of the middle and lower reaches of the Don Valley. Downstream toward and beyond Doncaster, vast areas of the former South Yorkshire Fenland (Rotherham, 2010, 2013b) were flooded for several weeks with communities forced from their homes and in some cases unable to return for nearly 2 years. A repeat event of similar intensity occurred in the winter of 2019-2020. Essentially, the wider catchment function of the River Don and its tributaries has been compromised (as described by Crowe and Rotherham, 2019) with the historic floodplain built on (in urban areas) or else farmed intensively (in rural areas). Even the headwaters of upland peatbogs around 10 miles from the city centre have been drained, burnt as grouse moor, and subsequently intensively grazed. This history of intensive management is now strongly associated with downstream flooding.

This breakdown of function relates largely to landscapes, physical structures, and processes all compromised. With watercourses straightened, controlled, canalised, and culverted there is a consequent breakdown of environmental services which now fail to operate (Table 2, from Crowe and Rotherham, 2019).

\section{Visions of the Past}

Our image of the "unspoilt" pre-urban and pre-industrial landscape is at best fuzzy. As noted in some detail by Firth (1997) and Rotherham (2010), the earlier landscape as described was by no means "natural" but already affected by massive drainage in both upper and lower catchments, and by the use of water-power from before Domesday. We are fortunate for this region to have accounts by leading historians such as the late David Hey and David Crossley, and by Melvyn Jones. There were also topographers and other writers back to the 1600 s or so. Nevertheless, there are limitations to these sources and so care is needed in their interpretation. Questions of who they were and who they were writing for spring to mind. Furthermore, whilst many early authors (e.g., Hunter, 1819) provided what they felt were factual accounts, they were not scientifically trained or minded, and so the sources are inherently descriptive. Ebenezer Elliot writing in 1840 was a 


\section{Stepwise transformation of ecology as observed on the River Don, Sheffield, UK}

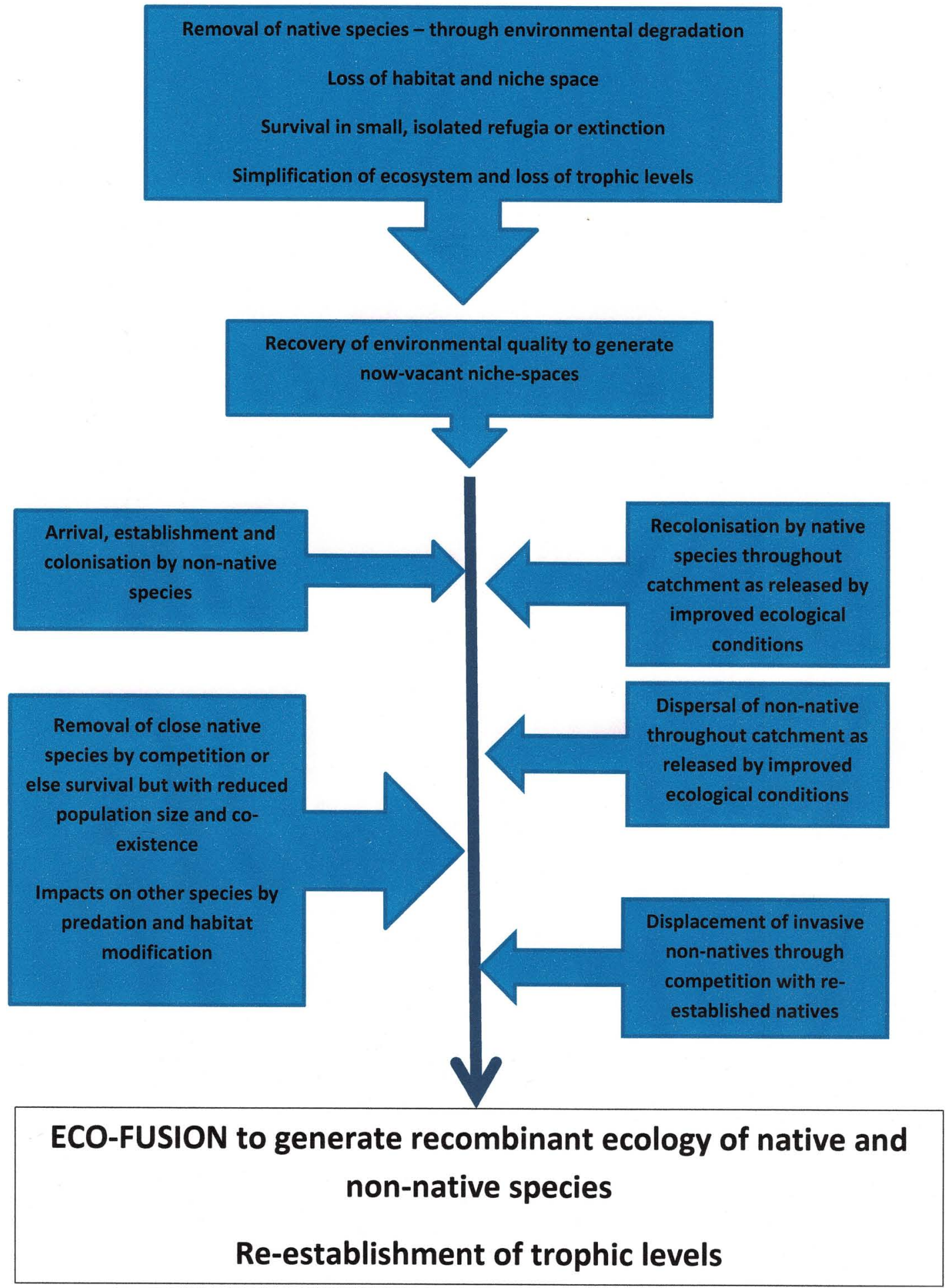

FIGURE 10 | Stepwise transformation of ecology as observed on the River Don, United Kingdom over a period from the 1600 s to the 2000 s. 
TABLE 2 | Summary of the River Don ecosystem service provision (from Crowe and Rotherham, 2019).

\title{
Drivers of change
}

Long-term studies and historical analysis allow an assessment of changes in ecosystem service delivery across the River Don catchment. It is already known that the region was prone to catastrophic flooding events in for example, the 1600s and 1700s (Rotherham, 2010, 2013b) and this trend continued throughout the 1800s, 1900s, and into the 2000s. The late medieval landscape was already much altered by human activities but from 1600 onward was subject to massive and widespread drainage schemes (Rotherham, 2010, 2013b) including the removal of around 2,000 square kilometres of lowland fen and peat bog. A similar scale of landscape change took place in the uplands around the headquarters of the Don and its sister rivers. Between the upland zone and the lowland floodplain the rivers were straightened, canalised, and in urban areas often culverted. Lands adjacent from the modified watercourses were drained and either farmed or else used for development. Alongside massive pollution across the region, these changes totally altered the associated ecological systems. Drainage and land "improvement" facilitated the construction of businesses, factories, hard infrastructure, and residential housing on the former floodplains now disconnected from the river system. Furthermore, the once "living" river was now fixed in its flood-banks and fossilised river channels. In essence, by the late twentieth century, the delivery of vital ecosystem services was failing and indeed, when flood-waters did burst the riverbanks then the human and financial costs were massive.

Finally, human-driven climate change and other environmental changes have exacerbated and already critical failure of the river system. The individual sections of the rivers from the upland headwaters to the lowland floodplain are considered in broad terms below.

\begin{tabular}{lll}
\hline $\begin{array}{l}\text { Section of the } \\
\text { river }\end{array}$ & Characteristics & $\begin{array}{l}\text { Ecosystem services } \\
\text { delivered }\end{array}$
\end{tabular}

Head-waters: Upland peat-dominated catchment

Upper reaches

Pastoral farmland and some woodland

Middle reaches

(1)

Middle reaches

(2)

\section{The lowest reaches}

Rural areas with extensive marshland converted to intensive arable farmland, some urban areas, some industry, major transport infrastructures
Water supply, C-sequestration, biodiversity, tourism, recreation, agriculture Water retention
Drainage, air pollution, over-grazing, burning, agricultural conversion

\author{
Restoration of peat bogs, blacking \\ of drains and grips, control of \\ air-pollution, reduction of grazing, \\ control of fires. Reintroduction and \\ conservation of key species at \\ higher trophic levels or \\ eco-architects such as beaver. \\ Enhancement of water retention \\ and carbon sequestration.
}

Water supply, C-sequestration, biodiversity, tourism, recreation, agriculture Water retention
Drainage, air pollution, over-grazing, agricultural conversion
Rural areas with woodland and farmland but more extensive urban zones

Rural areas with extensive fenland and bog converted to intensive arable farmland, some urban areas, some industry, major transport infrastructures
Water supply, biodiversity, recreation, health and wellbeing

Farming, biodiversity, recreation, health and wellbeing, C-sequestration, irrigation water

Farming, biodiversity, water-based transport, recreation, health and wellbeing, C-sequestration, Water storage

\section{Summary comments and analysis}

The broad types of land-use are described for the river sections.
The ecosystem services delivered and provided by each river section are summarised.
Drainage, air pollution, water pollution, canalisation, culverting Groundwater lowering unsustainably with nutrient enrichment, and other problems Drainage and conversion to intensive agriculture, air pollution, water pollution, canalisation, culverting Groundwater lowering unsustainably with nutrient enrichment, and other problems such as possible salination from sea-water moving in

Drainage and conversion to intensive agriculture, air pollution, water pollution, canalisation, culverting, reclamation of land for urbanisation and industry, industrial pollution. Intensive farming on drained former peatlands is releasing massive amounts of carbon to the atmosphere. The key drivers of change in each river section are summarised.
Possibly tree-planting, use of natural regeneration to trigger woodland development, less intensive farming, blocking of drains and grips at field level.

Enhancement of water retention and carbon sequestration. Control of pollution, day-lighting of watercourses, re-creation of floodplain wetlands, improved access to riverside, species reintroductions, new woodlands. Re-wetting of extensive cut-over peat bog, re-creation of floodplain wetlands, control of pollution, day-lighting of watercourses, improved access to riverside, species reintroductions, new woodland.

Control of pollution, improved access to riverside, species reintroductions, restoration of floodland, development of tourism as an economic driver for positive change. Enhancement of water retention and carbon sequestration.

Possible actions and necessary steps to remediate the problems are noted and summarised.

\section{Long-term consequences for recovery}

The recovery of ecosystems services across the River Don catchment has begun in part.

The major improvements have been in terms of urban and industrial pollution, the creation of new wildlife habitats, and the re-establishment of once extinct species and at higher trophic levels. Steps have also been taken in the upper catchment headwater zones to trigger the re-formation of extensive peat bogs but this is necessarily a long-term venture. In the lowlands, some core former peat bog sites such as at Thorne and Hatfield Moors (see Rotherham, 2010, $2013 \mathrm{~b})$ are being re-wetted. 


\section{TABLE 2 | Continued}

However, the disconnect between river and floodplain is still a major issue throughout the catchment and intensive farming of the lowland former fens still loses much carbon to the atmosphere, the land is consequently shrinking and becoming more flood-prone. It has been suggested that because of breakdown to carbon dioxide, and erosion by wind and water, fewer than fifty harvests remain in many of these soils. In urban areas some modest progress has been made to "daylight" former culverted rivers, and in rural zones some river meanders have been reinstated. All-in-all, some progress is being made. However, there is still a major lack of any larger-scale vision of a joined-up, long-term solution, and this remains as a significant challenge. Finally, whilst ecological recovery is underway throughout much of the catchment there is still significant eutrophication in the lower zones due to farm-related fertiliser runoff, and fumes from road traffic and power-station gasses. It is believed that these may still limit peatland recovery in the re-wetted, lowland peat-bogs.

The other key observation is that the nature of the ecology which is recovering from the nadir of the late twentieth century is that it is a recombinant ecological system of mixed natives and non-natives; and this situation will continue into the new futurescape.

nationally notable poet and a radical campaigner, the "CornLaw Rhymer." John Ruskin too, was one of the founders of the modern socialist movement and a campaigner against the horrors of Victorian urbanisation and pollution. Some of the writers of the twentieth century give us plain, dispassionate, scientific accounts of observations made (e.g., Hugill and Blacktin, 1929); whereas others like Orwell (1937) are openly political. With issues such as urban pollution and dereliction potentially very emotive, this tension between objective science and political lobbying has to be considered when sources are assessed. For example in the debates on water pollution in the 1980s, there is a contrast between say "The Poison Factory" by Greenpeace Anon (1994) and "Dioxins and the River Doe Lea" by the National Rivers Authority, Anon (1995). The politics and human impacts on the River Don catchment are discussed by Firth (1997) and in detail by Rotherham (2010, 2013b). Some insight into the earlier landscape can be gleaned from the Domesday account of 1086 and this is discussed in detail by Hey (1998), Jones (2009), and Rotherham (2017b), so overall there is a reasonably good idea of how this countryside was pre-industrialisation. But it was a landscape of nature shaped by human activity during the previous millennia.

This human driving of the eco-cultural landscape is also pertinent to the concepts of "recombinant ecologies" and is discussed in detail by Rotherham (2017a). In essence, the argument is that British ecological systems have been in part recombinant for over 2,000 years or more; and the concept includes both removal of species though extinction and the arrival and integration of newly acquired species through introductions. Viewed in this light questions concerning the "naturalness" of any prior condition before destruction and degradation are not directed at a pristine condition but one which is inherently eco-cultural. Ideas of the former countryside are also formed through the lens of the modern observer and the writings of those gone before. So we see a landscape reimagined in the case of the Don through for example the romantic novelists like Sir Walter Scott (1819) with his volume Ivanhoe set at Conisbrough in the heart of the Don Valley and hugely influential in forging future opinions and impressions. This idea is developed further in Rotherham (2010) for example, but a point to emerge from this present study is that "restoration" does not necessarily restore to a past condition but forward to a new futurescape. Furthermore, the point made but not dwelt on here, is that the past is itself in part at least, reimagined.

\section{The Changing Ecology}

The rivers which together make up the Don catchment have experienced the most dramatic turn-around in their environmental condition in perhaps around 50 years. This followed a long-running and seemingly inexorable decline since the middle ages and into the industrial period. However, these now post-industrial rivers are now in a state of rapidly improving ecology. In many ways the ecological and amenity improvements began to take shape with a vision from environmentalists and local industrialists in the 1970s (e.g., Anon, 1972, and undated). This began with a simple will to clean-up and tidyup the derelict rivers of the region but ultimately led to a much greater and more holistic recovery. There was also a significant degree of political embarrassment about a city where its rivers had to be hidden from view because they were foul, dead, open sewers. Such a situation also coincided with the major upturn in political ecology and the public expression of disgust at human disregard for nature and the degradation of the local environment (see Rotherham, 2014a, 2017c). In part led and facilitated by officers of the local authority (Sheffield City Council) and the then National Rivers Authority and Yorkshire Water plc, there were coordinated moves to cleanse the filth and recover a degree of environmental quality to this degraded system. Furthermore, both national and international legislation (such as the EU Water Framework Directive; see Cartwright, 2003) were beginning to have real impacts in shaping the restoration of urban watercourses. With moves to "green" the city (Bownes et al., 1991) and the Don Valley (Watts et al., 1987), there was a huge upsurge in public and political expression in favour of cleaning up and "restoring" the region's ecological systems (Rotherham, 2014a). Twenty to thirty years on, this movement has grown to include ideas of "rewilding” ecological systems' (e.g., Rotherham and Harrison, 2002; Rotherham, 2014b). With an ecological system such as the River Don catchment there arise major conceptual challenges of what the system is rewilded from and furthermore, what to.

Pollution levels have dropped considerably although localised problems of long-term contamination of river sediments remain in the watercourses and in the flood-plains. Physical degradation and disruption to the rivers remain problematic despite some re-landscaping to put back some meanders and limited floodplain water storage features. Perhaps most effective have been moves to help migrating fish negotiate the industrial weirs which increasingly barred their ways upstream since medieval 


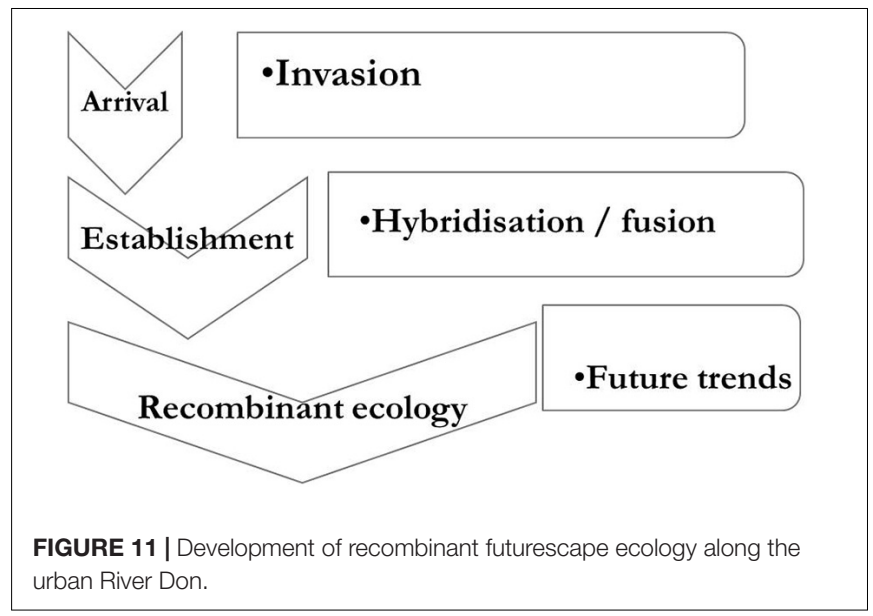

times. In recent years, we received records of dead and dying salmon from the upper Don and this suggests successful migration and spawning.

Along the entire catchment there has been a remarkable recovery of ecology and this varies from urban to rural stretches and from river to river. However, in the urban rivers especially, the ecological mixing from nearly zero biodiversity in the 1970s to the present day is not a replacement of the medieval landscape and ecology that was lost. What has emerged today is an intimate mix of native and of non-native plants and animals, i.e., a recombinant or hybrid ecology (see Rotherham, 2014a, 2017a) and this is driven by a process known as eco-fusion (Rotherham, 2017a; Figure 7). The emergence of hybrid ecologies as a new norm may be uncomfortable for many ecologists and conservationists, but it is the reality of what is happening.
The basic timeline of the recombination process is shown schematically in Figures 10, 11, and the process illustrated in Figure 12.

Invasion by both native and non-native species within the river system may or may not lead to establishment. However, as both natives and non-natives arrive into the vacant, available niches created by human impacts disrupting the earlier ecology, the mixing leads to "fusion" or "hybridisation" (Figure 11; Rotherham, 2017a), to recombination and ultimately to a futurescape ecology. The changes are driven by mixes of human influences and natural processes (Figure 12) but with this mixed palette of native and non-native (alien) fauna and flora.

\section{The Urban River Futurescape}

Post-industrial river recovery, especially in urban areas, is leading not to a return to original "natural" conditions but to a new recombinant ecological condition (Figure 10). This is a result of permanent change to the landscape; in the city to post-industrial urban development, and in rural areas to intensive agricultural usage. As pollution levels generally fall, the ecology recovers and through eco-fusion, emerges into a novel futurescape. In some cases, such as the interplay between native and alien crayfish and pollution levels, the recovery is to a new ecological community not a reversion to a "natural" state. A further driver of these changes is the shifting of climate and of wider environmental conditions through eutrophication, globalisation, cultural severance (Rotherham, 2008a, 2011b), and macrodisturbance (Rotherham, 2014b). Some level of ecosystem service has been restored to the catchment (see Crowe and Rotherham, 2019) but not all, and the ecology has largely recovered to include a full range of trophic levels. This recolonised ecology is a recombinant mix of native and non-native species. The implications for "restoration ecology" of these observations are,

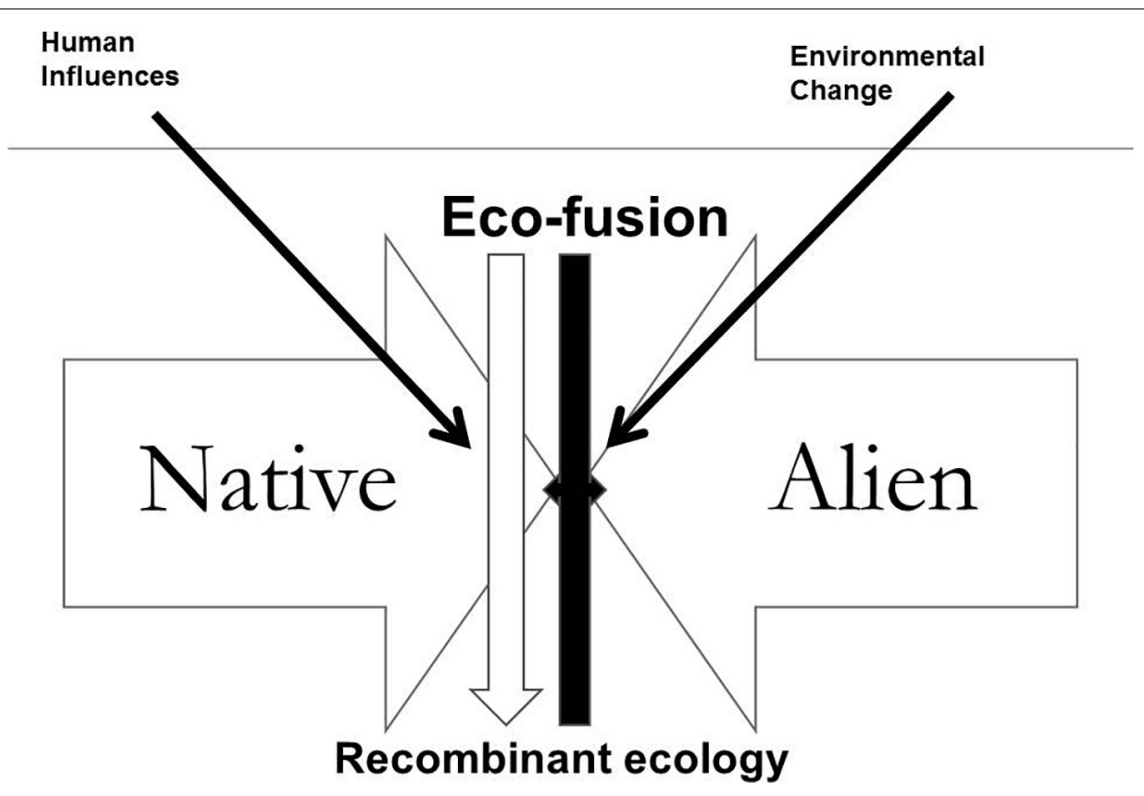

FIGURE 12 | Eco-fusion processes along the River Don (from Rotherham, 2017a). 
to say the least, significant. Some of the issues were discussed previously (e.g., Rotherham and Harrison, 2009; Rotherham, 2011b) and include the twin issues of recombinance in the ecology and cultural severance in terms of human impacts and drivers. The landscape pre-industrialisation and urbanisation, i.e., immediately prior to the great decline in environmental quality, was already much changed from a "natural" system and essentially "eco-cultural." In the post-industrial world, the ecological palette of available species has altered radically, and the human-cultural drivers have also transformed. In this context, the emergence of a new "futurescape" involves a recombinant ecological system and not a return to the old one. The "re-" in rewilding is problematic.

Finally, whilst some of the recovery can be rightfully ascribed in no small part to political champions and to environmental campaigners, it can also be argued that much has been achieved though self-directed natural processes. As heavy industry collapsed in the 1970s and new more rigorously controlled and environmentally constrained factories emerged in the 1990s, the pollution levels fell. Some of this decrease was due to legislation and controls but much was due to the closure of the polluting factories, coal-mines, and antiquated sewage treatment plants. With this release from highly toxic pollution, the rivers have to a large degree "self-rewilded"; a testimony to nature's powers of recovery but overlying a multilayered heritage of industry and other human impacts. The human imprint on the region's ecological systems is indelible. As discussed in Rotherham, 2017a,c) the processes at work are natural but here they are acting on a species palette which mixes natives and non-natives without discrimination. However,

\section{REFERENCES}

Amishah, S., and Cowx, I. G. (2000). Response of the fish populations of the Rover Don in South Yorkshire to water quality and habitat improvements. Environ. Pollut. 108, 191-199. doi: 10.1016/s0269-7491(99)00190-6

Anon Interim Report of River Don Steering Group. Leeds: Sheffield Junior Chamber of Commerce, 7.

Anon (1897). The Architecture of our Large Provincial Towns. X. Sheffield. The Builder. unpaged.

Anon (1972). Re-vitalization of the River Don. Sheffield: Sheffield Junior Chamber of Commerce. unpaged.

Anon. (1986). A Review of Air Pollution in The Lower Don Valley 1986. Sheffield: Environmental Health \& Consumer Services Dept., Sheffield Metropolitan District Council, 25.

Anon. (1988). Water Quality Report. Leeds: Yorkshire Water. unpaged.

Anon. (1994). The Poison Factory - the story of Coalite Chemicals. London: Greenpeace, 27.

Anon. (1995). Dioxins and the River Doe Lea. Leeds: National Rivers Authority. unpaged.

Anon. (2002). Water Relieffor Villagers. York: The York Press.

Barfield, P. (2001). An Investigation into Mercury Contamination in the Sediments Deposited on the Banks of the River Don in Rotherham. Sheffield: Sheffield Hallam University, 69. Unpublished BSc Research Project.

Belshaw, T. (2000). Newspaper Article-So What Would John Ruskin Have Made of the Latest Exhibition at the Gallery Which Proudly Bears his Name? Sheffield Star Newspaper, $16^{\text {th }}$ February, 2000. Sheffield: Sheffield Newspapers. unpaged.

Bownes, J. S., Riley, T. H., Rotherham, I. D., and Vincent, S. M. (1991). Sheffield Nature Conservation Strategy. Sheffield: Sheffield City Council, 99.

Bridgewater, P., and Rotherham, I. D. (2019). Biocultural diversity and its role in nature conservation and heritage. People Nat. 1, 291-304. for restoration ecology and conservation ecologists troubled by non-native species (see Rotherham, 2011a for example), the implications of these processes and their outcomes trigger a degree of angst. Yet the visionary writing of Gilbert (1989, 1992a,b) predicted exactly this scenario of a new nature. In his seminal 1992a paper on the urban River Don, Gilbert noted the "natural" recolonisation by "native" plants of the now partly self-cleansed river system. His key observation perhaps, was the appearance of typical ancient woodland flowers under the pseudo-woodland canopy provided by gardenescapee, Japanese knotweed. In the early 2000s, we were able to add the observation of native otters also back on the urban river and also under the shelter of the dense knotweed canopy. Both observations are the unexpected and unintended outcomes of human-nature paradigms. At the time, Gilbert described Japanese knotweed as a distinctive and perfectly appropriate urban plant.

\section{DATA AVAILABILITY STATEMENT}

The original contributions presented in the study are included in the article/supplementary material, further inquiries can be directed to the corresponding author/s.

\section{AUTHOR CONTRIBUTIONS}

The author confirms being the sole contributor of this work and has approved it for publication.

Cartwright, G. A. (2003). Wetland Enhancement on an Urban River: Issues of Social and Economic Regeneration. M. Phil. Thesis, Sheffield Hallam University, Sheffield.

Clarkson, K., and Garland, S. (1988). Colonisation of Sheffield's Urban Wastelands - Vascular Plants. Sorby Rec. 25, 5-78.

Crossley, D. (ed.) (1989). Water Power on the Sheffield Rivers. Sheffield: Sheffield Trades Historical Society \& University of Sheffield, 127.

Crowe, L., and Rotherham, I. D. (2019). "Biodiversity and Ecosystem Services in Relation to the Management of Storm Water and the Mitigation of Floods," in Urban Stormwater and Flood Management. Enhancing the Liveability of Cities, ed. V. Jegatheesan (Cham: Springer), 159-186. doi: 10.1007/978-3-030-11818$1 \_8$

Edwards, A. (1996). "Salmon in the Don- Who Pays?," in Proceedings of a Conference- Towards a Sustainable Future for the River Don, ed. A. Edwards (Sheffield: National Rivers Authority). unpaged.

Edwards, A. (1997). Local Environment Agency Plan- South Yorkshire and North Derbyshire (Consultation Report). Leeds: Environment Agency. unpaged.

Edwards, A. (1998). Local Environment Agency Plan- South Yorkshire and North East Derbyshire. Leeds: Environment Agency, 49.

Edwards, A. (1999). Local Environment Agency Plan- South Yorkshire and North East Derbyshire. Leeds: Environment Agency, 41.

Elliot, E. (1840). The Poetical Works of Ebenezer Elliott, the Corn-Law Rhymer. Edinburgh.

Firth, C. (1997). 900 Years of the Don Fishery: Domesday to the Dawn of the New Millennium. Leeds: Environment Agency. unpaged.

Firth, C. (2018). "Sustainability or Bust: The Fall and Rise of The Don's Fish Population," in Back From The Edge: The Fall and Rise of Yorkshire's Wildlife, eds M. Atherden, C. Handley, and I. D. Rotherham (Sheffield: Wildtrack Publishing), 63-72. 
Gilbert, O. L. (1989). The Ecology of Urban Habitats. London: Chapman and Hall, 369.

Gilbert, O. L. (1992a). The ecology of an urban river. Br. Wildlife 3, 129-136.

Gilbert, O. L. (1992b). The Flowering of The cities, The Natural Flora of 'Urban Commons'. Peterborough: English Nature, 36.

Griffiths, P. (1989). The Five Weirs Walk (Sheffield East End History Trail No 3): Five Weirs Walk No. 3 Paperback. Sheffield: Five Weirs Walk Trust. unpaged.

Griffiths, P., Simpson, F., and Rotherham, I. D. (1996). Hydrology and Water Quality in the Upper Don Catchment. Results of the Research Feasibility Study and Proposals for Further Research. Sheffield: Sheffield Centre for Ecology and Environmental Management. unpaged.

Hey, D. A. (1998). History of Sheffield. Ashbourne: Moorland Publishing, 264.

Hugill, W. (1929). "The study of atmospheric pollution in the Sheffield District. Part II. The effect of smoke on life and buildings," in Proceedings of the Sorby Scientific Society, Vol. 1, (Sheffield), 77-78.

Hugill, W., and Blacktin, S. C. (1929). "The study of atmospheric pollution in the Sheffield District. Part I," in Proceedings of the Sorby Scientific Society, Vol. 1, (Sheffield), 71-76.

Hunter, J. (1819). Hallamshire. The History and Topography of the Parish of Sheffield: with Historical and Descriptive Notices of the Parishes of Ecclesfield, Hansworth, Treeton and Whiston, and of the Chapelry of Bradfield, 1869 Edn. Sheffield: Pawson and Brailsford, 508.

Jones, M. (2009). Sheffield's Woodland Heritage. Sheffield: Wildtrack Publishing, 74.

McClarence, S. (1988). Sheffield Walkabout. Sheffield: Sheffield City Libraries. unpaged.

Orwell, G. (1937). The Road to Wigan Pier. London: Victor Gollanz, 240.

Rosenthal, L. (2014). The River Pollution Dilemma in Victorian England. Farnham: Ashgate, 253.

Rotherham, I. D. (1983). The Ecology of Rhododendron ponticum L. with Special Reference to its Invasive and Competitive Capabilities. Ph.D thesis, University of Sheffield, Sheffield, 275.

Rotherham, I. D. (1986). The Wildlife and Geology of the Lower Don Valley - A Preliminary Report June 1986. Sheffield: Natural Sciences Section, Museums Department, Sheffield City Council. unpaged.

Rotherham, I. D. (1987). Wildlife \& Leisure in the Lower Don Valley. Sheffield: Natural Sciences Section, Museums Department, Sheffield City Council. unpaged.

Rotherham, I. D. (2001a). "Himalayan Balsam- the human touch," in Proceedings of the $11^{\text {th }}$ Conference of the Institute of Ecology and Environmental Management, Birmingham, Exotic Invasive Species- should we be concerned?, ed. P. Bradley (Winchester: IEEM), 41-50.

Rotherham, I. D. (2001b). Rhododendron gone wild - conservation implications of Rhododendron ponticum in Britain. Biologist 48, 7-11.

Rotherham, I. D. (2001c). Urban deer: a south yorkshire case study. Deer 11, $566-569$.

Rotherham, I. D. (2003). "Deer in urban and urban fringe areas - trends, issues and challenges," in Proceedings of the Future for Deer Conference, English Nature Research Reports No. 548, ed. E. Goldberg (Peterborough: English Nature), 40-48.

Rotherham, I. D. (2005a). Alien plants and the human touch. J. Pract. Ecol. Conserv. Spec. Ser. 4, 63-76.

Rotherham, I. D. (2005b). Invasive plants - ecology, history and perception. J. Pract. Ecol. Conserv. Spec. Ser. 4, 52-62.

Rotherham, I. D. (2008a). "Chapter 4: The importance of cultural severance in landscape ecology research," in Landscape Ecology Research, eds A. Dupont and H. Jacobs (New York, NY: Nova Science Publishers Inc), 71-87.

Rotherham, I. D. (2008b). Floods and water: a landscape-scale response. Pract. Ecol. Conserv. 7, 128-137.

Rotherham, I. D. (2008c). Landscape, water and history. Pract. Ecol. Conserv. 7, $138-152$.

Rotherham, I. D. (2010). Yorkshire's Forgotten Fenlands. Barnsley: Pen \& Sword Books Limited, 176.

Rotherham, I. D. (2011a). "Chapter 15: History and perception in animal and plant invasions - the case of acclimatisation and wild gardeners," in Invasive and Introduced Plants and Animals: Human Perceptions, Attitudes and Approaches to Management, eds I. D. Rotherham and R. Lambert (London: EARTHSCAN), $233-248$.
Rotherham, I. D. (2011b). “The implications of landscape history and cultural severance in environmental restoration in England," in Integrating Nature and Culture: The Human Dimensions of Ecological Restoration, eds D. Egan, E. Hjerpe, and J. Abrams (Washington DC: Island Press), 277-287. doi: 10.5822/ 978-1-61091-039-2_19

Rotherham, I. D. (2013a). Lost Sheffield in Colour. Stroud: Amberley Publishing, 126.

Rotherham, I. D. (2013b). The Lost Fens: England's Greatest Ecological Disaster. Stroud: The History Press, 207.

Rotherham, I. D. (2014a). Eco-History: A Short History of Conservation and Biodiversity. Cambridge: The White Horse Press, 253.

Rotherham, I. D. (2014b). The call of the Wild. Perceptions, history people \& ecology in the emerging paradigms of wilding. ECOS 35, 35-43.

Rotherham, I. D. (2017a). Recombinant Ecology - a Hybrid Future. Dordrecht: Springer, 85.

Rotherham, I. D. (2017b). Shadow Woods: A Search for Lost Landscapes. Sheffield: Wildtrack Publishing, 258.

Rotherham, I. D. (2017c). "The industrial transformation of South Yorkshire landscapes," in The Industrial Legacy \& Landscapes of Sheffield and South Yorkshire, eds I. D. Rotherham and C. Handley (Sheffield: Wildtrack Publishing), 3-40.

Rotherham, I. D. (2018a). Steel City: An Illustrated History of Sheffield's Industry. Stroud: Amberley Publishing, 96.

Rotherham, I. D. (2018b). "Times they are a changing, looking back to the future for Yorkshire's wildlife," in Back From The Edge: The Fall and Rise of Yorkshire's Wildlife, eds M. Atherden, C. Handley, and I. D. Rotherham (Sheffield: Wildtrack Publishing), 109-114.

Rotherham, I. D. (2018c). "Yorkshire's forgotten Fenland," in Back From The Edge: The Fall and Rise of Yorkshire's Wildlife, eds M. Atherden, C. Handley, and I. D. Rotherham (Sheffield: Wildtrack Publishing), 3-22.

Rotherham, I. D., and Cartwright, G. (2000). The potential of Urban Wetland Conservation in economic and environmental renewal- a case study approach. Pract. Ecol. Conserv. 4, 47-60.

Rotherham, I. D., and Cartwright, G. (eds) (2006). "Water and wetlands: their conservation and re-creation in a social landscape - the vital role of project champions," in Proceedings of the IALE Conference, Water and the Landscape: The Landscape Ecology of Freshwater Ecosystems, (Reading: IALE), 321-326.

Rotherham, I. D., and Derbyshire, M. J. (2012). Deer in and around the Peak District and its urban fringe. Br. Wildlife 23, 256-264.

Rotherham, I. D., and Harrison, K. (2002). "Wilding by design as a future driver for a new nature in reconstructing South Yorkshire's Fens," in Wild by Design and Ploughing on Regardless. Landscape Archaeology and Ecology Special Series. Papers from the Landscape Conservation Forum, eds I. D. Rotherham and C. Handley (Sheffield: Wildtrack Publishing), 54-72.

Rotherham, I. D., and Harrison, K. (2009). "South Yorkshire Fens Past, Present and future: ecology and economics as drivers for Re-wilding and Restoration?, in Greening History: The Presence of the Past in Environmental Restoration, ed. M. Hall (London: Routledge Publishing), 143-153.

Rotherham, I. D., Cooper, A., Ely, W., Handley, C., Croxton, R., Glasscock, J., et al. (1994). River Rother Wildlife Strategy-A Joint Local Authorities Initiative. Sheffield: Sheffield City Council. unpaged.

Salt, J. (1889). List of Plants Collected Chiefly in the Neighbourhood of Sheffield by Jonathan Salt and Now in the Sheffield Public Museum. Herbarium Catalogue by E. Howarth. Sheffield: the Sheffield Literary \& Philosophical Society.

Scott, W. (1819). Ivanhoe: A Romance. London: Hurst, Robinson, and Co, 401.

Shaw, M. R. (1972). Vegetation of the Industrial Don. Part 1. Sorby Rec. 3, 13-15.

Shaw, M. R. (1974). Vegetation of the Industrial Don. Part 2. Sorby Rec. 13, 54-56.

Shaw, M. R. (1976). Vegetation of the Industrial Don. Part 3. Sorby Rec. 14, 67-68.

Shaw, M. R. (1978). Vegetation of the Industrial Don. Part 4. Sorby Rec. 16, 29-31.

Shaw, M. R. (1979). Vegetation of the Industrial Don. Part 5. Sorby Rec. 17, 30-33.

Shaw, M. R. (1981). Vegetation of the Industrial Don. Part 6. Sorby Rec. 19, 30-33.

Shaw, M. R. (1988). Vegetation of the Industrial Don: reappraisal. Sorby Rec. 25, 58-78.

Walton, M. (1948). Sheffield-its Story and its Achievements. Sheffield: The Sheffield Telegraph and Star Ltd, 260. 
Warman, C. R. (1969). Sheffield Emerging City. Sheffield: The City Engineer and Surveyor and Town Hall Planning Officer.

Watts, R., Pearson, R., and Rotherham, I. D. (1987). New Life for the Lower Don Valley. Landsc. Design 165, $16-19$.

Wild, M., and Gilbert, O. (1988). Sheffield Inner City Habitat Survey. Sheffield: Sheffield City Wildlife Group.

Yorkshire Water Local Improvements On-Line. Available online at: https: //www.yorkshirewater.com/about-us/what-we-do/investment-near-you/ (accessed September 22, 2020).
Conflict of Interest: The author declares that the research was conducted in the absence of any commercial or financial relationships that could be construed as a potential conflict of interest.

Copyright $(\odot 2021$ Rotherham. This is an open-access article distributed under the terms of the Creative Commons Attribution License (CC BY). The use, distribution or reproduction in other forums is permitted, provided the original author(s) and the copyright owner(s) are credited and that the original publication in this journal is cited, in accordance with accepted academic practice. No use, distribution or reproduction is permitted which does not comply with these terms. 